\title{
Trauma ja elulood ${ }^{1}$
}

\author{
Tiiu Jaago \\ Tartu Ülikooli kultuuriteaduste instituudi \\ eesti ja võrdleva rahvaluule osakonna dotsent \\ tiiu.jaago@ut.ee
}

\begin{abstract}
Teesid: Artikli keskmes on traumaatilise kogemuse esitamise viisid eesti elulugudes. Kahe eluloojutustuse näitel vaadeldakse, kuidas 20. sajandi lõpul ja 21. sajandi alguses jutustatud elulugudes kõneldakse traumaatilistest kogemustest, mis asetuvad 20. sajandi ajaloosündmuste raamidesse (Esimene ja Teine maailmasõda, poliitilised vangistused). Ühtlasi küsitakse, kuidas on elulugudest ilmnev traumaatiline kogemus suhestatav traumateooriast lähtuvate kontseptsioonide ja uurimistulemustega. Kui traumateooria võimaldab analüüsida ühiskonnas aktuaalseid ja kultuuriüleseid traumailminguid ning esitusviise, siis elulugudes tulevad esile trauma individuaalsed, lokaalsed ja kultuurisidusad aspektid. Elulugudes esitatakse traumaatilised kogemused ühitatuna neist saadud õppetunni ja moraalse kokkuvõttega, kuidas rasketes olukordades toime tulla. Samas sisaldub eluloos viiteid traumaatilistele kogemustele, mida otsesõnu ei avata ja mille uurimiseks on vaja leida lisaallikaid. Ka tuleb rõhutada, et avalikest aruteludest ja traumateooriast lähtuvad aspektid ei kattu elulugudes esitatuga. Et kirjeldada individuaalsete ja avalike traumateemade seoseid, tuleb esmalt vaadelda traumaatilisi kogemusi nende avaldumiskontekstis, teiseks näha otseste mõjuseoste asemel kokkupuutepunkte ja dialoogi.
\end{abstract}

Märksõnad: elulugu, folkloristika, traumaatiline kogemus, traumateooria

Artiklis käsitletakse elulugudes avalduvat traumaatiliste kogemuste teemat folkloristliku jutu-uurimise seisukohast. ${ }^{2}$ Sotsioloogias ja kirjandusteaduses on traumaatiliste kogemuste valdkonda trauma- ja mäluteoreetilisest vaatepunktist küllaltki laiaulatuslikult uuritud, sh ka Eestis (nt Kirss 2002, 2003, 2006, 2013; Aarelaid-Tart 2006, 2016; Kurvet-Käosaar 2008, 2014; Hollo 2016; Laanes 2016/2017, 2017). Kirjandustekstide analüüsis pöörab Tiina Kirss muuhulgas tähelepanu rahvaluulemotiividele, mainides seejuures ka Eda Kalmre Teise maailmasõja järgsete kuulujuttude teemalist uurimust (Kirss 2013: 38). 
Kirjanduse ja rahvaluule seosed puudutavad vägivallast tingitud kummituskujutlusi, mille kaudu väljendatakse hirmu, ohutunnet vms. Ka kummituslugude folkloristlikus uurimises on tähelepanu pööratud nende tekstide sisu ja jutustamise seostele sotsiaalsete ja kultuuriliste konfliktide ning stressiga, mis leiavad aset tõsielus (Kalmre 2007: 189; Thomas 2007: 31). Paraku muutub rahvaluulemotiivide kasutus ja sellega seoses ka nende tähendus kiiresti (nagu antud juhul muutuvad hirmulood aja jooksul naljalugudeks või ka sõjajärgsete aastate meeleolusid kirjeldavaiks lugudeks), mistõttu motiivide traumaseos ei ole püsiv ega ainuline. Samas on aga ilmne, kui viljakat uurimispinda rahvaluule endast kujutab, kui analüüsida muistendi- vms jutumotiive traumaaspektist lähtudes.

Siinse folkloristliku käsitluse allikmaterjaliks ei ole aga kuulujutud, vaid elulood. Need sisaldavad traumaesitusi üksikisiku vaatepunktist, kus jutustamisel on peetud silmas kohalikku jutustamistava. Lähemaks vaatluseks on kaks käsikirjalist elulugu, mis pärinevad Eesti elulugude kogust (EKLA f 350). ${ }^{3}$ Üldisema tausta nende lugude siinsele tõlgendusele loovad varasemad elulookäsitlused sellistel teemadel nagu stalinliku vangilaagri kujutamine, enesevaatlus äärmuslikes tingimustes, tagasivaade sõjaajale, sõjajärgsete aastate kujutamine 1950. aastatel sündinute elulugudes (Jaago 2003, 2006: 93-96, 2007, 2014). Vaadeldavate elulugude jutustamise ajendiks ei ole olnud traumaloo esitamine, mistõttu trauma määratlemine ja vaatlus lähtub uurijapoolsest tõlgendusest.

Folkloristliku ja ühtlasi kultuurisidusa jutustamise ning konkreetse traumakogemuse analüüsi kõrval on võimalik kõnelda ka traumateoreetilisest lähenemisviisist. Kuigi need lähenemisviisid on erisuunalised (lähtumine ühel juhul jutustusest ja selles avalduvast kogemusest, teisel juhul traumateoreetilisest kontseptsioonist), on nende vahel ühenduspunkte, mis ärgitab neid seoseid lähemalt vaatlema. Artikli algusosa on pühendatud trauma kontseptsioonile üldisemalt, fookusega elulugudel. Artikli teise osa moodustab elulugude analüüs.

\section{Saatus ja trauma - elulood ja teooria}

Kuidas uurija saab määratleda traumat lugudes, mille jutustamisel traumakogemusest ega trauma teoreetilisest kontseptsioonist teadlikult ei lähtuta (viimane oleks võimalik näiteks teemaintervjuu puhul, kus uurija osaleb tekstiloomes)? Kui minu eesmärk elulugude lugemisel ei olnud piiritleda traumat uurimisobjektina, siis olen lugudest väljakirjutuste tegemisel spontaanselt traumana määratlenud laste ebakindlust sõjaolukorras (kus mingil põhjusel on kaduma läinud nende usaldus vanemate vastu). Samuti hirmu, olgu selle põhjuseks siis rinde lähedus või eeldus, mida võib kaasa tuua nõukogude 
võim. Selle määratluse kriteeriumiks on omaaegse hirmutunde aastakümneid kestnud järelmõju. Rutt Hinrikus on seevastu määratlenud traumalugudeks need, milles kajastatakse 1940. aastate pöördelisi sündmusi (Hinrikus 2016). Mõlemad aspektid (nii omaaegsete sündmuste järelmõju kui ka pöördeliste ajaloosündmuste kajastamine) sisalduvad traumateoorias. Samas eristub "trauma" oskussõnana selle sõna tavakasutusest ja -tähendusest, kus uurija võib traumana määratleda nähtusi, mida jutustaja nii ei nimeta (vrd Bal 2002: 33). Näiteks kirjutab Tiina Kirss: kui trauma "on uurija-poolne tõlgenduslik mall, mida kirjutaja ise ei tarvitse teada ega teadvustada", võib sellest "mallist" kujuneda norm ehk „valitsev tõlgendus“ (Kirss 2006: 617). Seega on uurija esmaseid ülesandeid leida tasakaal uuritava teksti ja teoreetilise lähenemisviisi vahel. Antud juhul on oluline see, et elulugudes üldiselt trauma mõistet ei kasutata. Küll aga väärib selles kontekstis tähelepanu "saatus" (vt nt Huima 2002; Kirss 2003: 241). Nii "trauma" kui ka "saatus" osutavad loo (mina)tegelase teatavale passiivsusele kirjeldatavate sündmuste keerises: nagu trauma puhul ei ole ohvril kuigi palju võimalusi olukorda muuta, vähemalt vägivalla raamidest läbi murda, nii ei pääse keegi ka oma saatusest. Nii saatuse kui trauma puhul on olemas ka aktiivne, olukordi põhjustav tegutseja. Ent erinevalt traumast ei kujunda saatust ratsionaalselt tõlgendatav jõud (samas väljendustasandil võib trauma ilmneda just irratsionaalsena, vt nt Kirss 2013). Mõlemat seostatakse nii ajalooliste kui ka isikliku elu sündmustega (viimasel juhul on näiteks saatusega seostatav kohtumine tulevase abikaasaga ${ }^{4}$ ). Oluline on, et see sündmus muudab inimese elu ja kujundab tema käekäiku. Võib täheldada, et saatus ja trauma sarnanevad teineteisele hetke- ja kestvusseostes: mõlemad ilmnevad konkreetse sündmusena, millest lähtuvad edasised arengud. Ja neid sündmusi tõlgendatakse trauma või saatuse kaudu. Mõlemad on oma loomult mitmetasandilised ja pidevas arengus olevad protsessid.

"Saatuse" kasutus rahvaluules viitab individuaalse ja biograafilise käekäigu kirjeldamisele. "Saatust" võib kohata 19. sajandi lõpust alates kirja pandud uuemates (lõppriimilistes) lauludes, ent see puudub vanemates, regivärsilistes lauludes, nagu ka klassikalistes mõistatustes. ${ }^{6}$ Lauludes võib saatus olla kaitsja ("meid kaitseb saatus igal aal") ja saatusega tuleb leppida ("eks rahul pea olema, [---] mis saatus mulle osaks and"). Enamasti kaasneb saatuse mainimisega mingi raske olukord - vangipõlv vms. Siis on saatus "vali" või "raske". Ka Jakob Hurdale rahvaluulet saatnud korrespondendid on oma kirjades maininud enda "kurba saatust". ${ }^{7}$ Igal juhul seostub "saatus" elukäigu ettemääratusega ja seda sõna kasutatakse nimelt eluloolises kontekstis. Vanasõnades kohtab "saatust" harva, ent neistki näidetest tuleb esile inimese sõltuvus inimvälisest jõust: "Saatusega ei saa kohtusse minna"; "Põllumees on saatuse ori". ${ }^{8}$ Kõnekäändude abil selgub, et saatust ei võrdsustata jumalaga ("annab saatuse jumala 
hooleks" - inimene ei muretse, vaid laseb asjadel omasoodu minna). ${ }^{9}$ Ühtlasi viitab see võimalusele, et kuigi oma saatusest ei pääse keegi, saab selle eest siiski ka ise kuidagi hoolt kanda.

Piir "saatuse" olemasolu või puudumise vahel kattub 19. sajandi suulise ja kirjaliku kultuuri vahealaga (regilaul, klassikalised mõistatused versus lõppriimiline laul). See viib oletusele, et saatus seostub kirjakultuurile omase individuaalsuse, kordumatusega, vastukaaluks suulise kultuuri (mitte suulise esituse, vaid kultuuritüübi) üldistuslikkusele, jätkuvale korduvusele. Ühtlasi võib küsida, mis oli "saatuse” kohal suulise kultuuri ajajärgul (ehk kuidas piiritleda saatust näiteks regilauludes)? Ent jäägu see arutelu mõneks järgmiseks korraks, et pöörduda tagasi saatuse ja trauma seoste juurde.

Kuidas seostada omavahel eluloo "saatus" teoreetilise "traumaga"? Esmaseks lähtepunktiks on eeldus, et mõlemal juhul on loo peategelane mingi temast väljaspool oleva jõu mõjuväljas. Saatuse puhul ei pea see olema vältimatult negatiivne, ent negatiivsena kogetavaid saatuse määratud sündmusi ja olukordi saab vaadelda traumat tekitavatena. ${ }^{10}$ Erinevalt saatusest ei määratle trauma aga kogu elukäiku, vaid seostub episoodidega, mis mõjutavad loo peategelast teataval määral ja viisil. Nii haakub trauma pigem teemajutustuse ${ }^{11}$, saatus aga eluloojutustusega, kus on tagasivaateid, tõlgenduskihte ja eluloosündmuste omavahelisi põimimisi enam kui tõsielule tuginevas teemaloos. Kuigi kirjeldustes võib trauma, eriti aga saatuse põhjustaja olla kujutatud anonüümsena, kindlate piirjoonteta või ebamäärasena, on saatusest erinevalt trauma põhjustajaks inimlik või looduslik jõud. Sellest tulenevalt saatusega ei vaielda ja saatusest tulenev kahju eeldatavaks korvajaks on elu ise. Traumaga seonduva võib aga kahtluse ja vastulöögi alla seada, kui sel on inimlik mõõde. Saatuse ja trauma ühisjooneks võib pidada nende mitmetasandilisust: kuigi mõlemal juhul kõneldakse tõsielusündmustest, jõutakse saatuse või trauma juurde sündmuste ja nende mõju üle arutlemise kaudu. Võib eeldada, et rahvapärane "saatus" juhib eluloouurija trauma juurde, ent kuna tegemist on akadeemilise kontseptsiooniga, on vaja heita pilk ka selle kontseptsiooni piirjoontele.

\section{"Trauma" kultuuriuurimises}

Meditsiinist ja psühhiaatriast pärit mõiste "trauma" on 20. sajandi teisel poolel üle kandunud ühiskonna valu- ja kannatuskogemuste märkimisele. Selle lähenemisviisi ajalooliseks tuumaks peetakse juudi genotsiidi käsitlusi, mille raames loodi ühelt poolt Euroopa ajaloo sündmustele ja teisalt Ameerika ühiskonna väärtustele tuginedes holokausti kujutavad sümbolid (Rothe 2011). Traumateemalistes avalikes, sh massimeedias vahendatavates aruteludes koon- 
dus tähelepanu vägivallale ja selle ohvritele (vrd Laanes 2017: 243). ${ }^{12}$ Samal ajal kerkis esile ka küsimus vastutusest - kui inimesed on kogenud vägivalda (nt Hiroshima, holokaust, totalitaarse riigi repressioonid), on keegi selle esile kutsunud ja peab seega oma tegude eest ka vastutama (Meek 2015). Nii on sündmuste ja nende tõlgendamiste kõrval traumakäsitlustes kesksel kohal vastutuse võtmise, andekspalumise ja -andmise teema. Siin võib näha ka saatuse ja trauma üht erinevust: saatuse puhul ei eristu sündmustes osalejad nii selgelt ja ühemõtteliselt vastaspoolteks (nt põhjustaja ja kannataja). Nii ei saa ka moraali teema saatuse puhul kõneks tulla ootuses, et keegi võtaks vastutuse (mis ei välista arutelu ebaõigluse või ülekohtutunde ja selle tekitaja üle). ${ }^{13}$

Praktilistes uurimustes on trauma mõistet kasutatud siiski suhteliselt vabalt (vt Leydesdorff jt 1999). Erinevaid suundi traumauurimises võib näha mõistekasutuses, näiteks avalikkuse ja ühiskonnatasandi uurimisel kasutatav "kultuuritrauma" (Aarelaid-Tart 2006), sündmustele keskenduv "ajalooline trauma" (Hollo 2016) ja sellega haakuv ärevustunnet tekitav "struktuuriline trauma”, mis viitab millegi eksistentsiaalselt olulise (kodu, lähedased) kaotamisele, sellest ilmajäämisele (LaCapra 2014: 82), massikultuuri-ilminguid hõlmav "traumakultuur" (Rothe 2011) või üldine "trauma", "traumauuringud" ja „traumateooria“(LaCapra 2014; Kirss 2002). Kuid olgu siis uurimisfookuses enam kollektiivne-kogukondlik või indiviiditasand, enam ajaloosündmuste või nendest kõnelemise tasand, enam sotsioloogiline või pigem jutu-uurimuslik tasand - trauma on seostatav märgatava identiteedimuutusega, mille on põhjustanud järsud muutused kas inimese või ühiskonna elus, sh sõjad, katastroofid, aga ka püsiväärtuste ohustamine või tähenduslike objektide lõhkumine (vrd nt Debs 2012; Aarelaid-Tart 2016; Talebreza-May 2015). Oluline on, et trauma eeldab sündmuste või olukordade järelmõju ja selle teadvustamist (KurvetKäosaar 2008: 136-137). Trauma mõiste seob erinevaid uurimisvaldkondi, mis traumaatiliste kogemuste uurimisega ühel või teisel moel tegelevad (nt ajalugu, kirjandus- ja kultuuriteadused, psühholoogia, ühiskonnateadused jne).

Traumauuringute aktualiseerumist 20. sajandi lõpul ja 21. sajandi alguses on põhjendatud ühiskonna arengu järskude muutustega, sh eriti globaliseerumise ja infotehnoloogia arenguga, millega kaasneb sotsiaalmeedia osatähtsuse esiletõus (Aarelaid-Tart 2016 [2010]). Uus geopoliitiline ja kommunikatiivne olukord sundis seni piiritletud aladel ja kultuurides väljakujunenud tõekspidamisi läbi vaatama nüüd juba mitmete kultuuride kokkupuutes. Just see aspekt toob traumauuringutes esile küsimuse identiteedist ja selle muutumisest. Millised traumaatilised kogemused on 20. ja 21. sajandi vahetuse avalikkuses esilekerkivateks teemadeks? Eestis on selleks näiteks nõukogude võimu kehtestamisest lähtunud repressioonid, nn eesti ja vene küsimus, Teises maailmasõjas Saksa sõjaväes teeninute ja metsavendade vastupanu teema, teatud viisil ka 
holokaust (Aarelaid-Tart 2016: 46 jj; Hinrikus 2016 [2003]: 268-273; Laanes 2016/2017). Samas võiks Eesti seisukohast päevakorral olla ka pärisorjuse teema, ent tänapäeva avalikkuses see kindlasti nii ei ole. On ilmne, et ühiskonnas esilekerkivad traumateemad ei hõlma kõiki võimalikke traumaatilisi kogemusi. Kui 20. sajandi lõpul jutustatud elulugudest võib leida üksikuid viiteid 19. sajandi olukordadele, siis need ei ole aktuaalsed kultuuritrauma vaatepunktist. Näiteks 1918. aastal sündinud naine esitab oma eluloos retoorilise küsimuse meeste varase surma kohta: olles üle elanud oma abikaasa ja 1990. aastatel ka poegade surma, arutleb ta, et nii on olnud ajast aega. Ta küsib: kuhu need mehed siis jäid? Esimene selles näitereas on jutustaja vanavanaisa Palo Jakob, kelle "tappis 50-selt mõisnik" (EKLA f 350, 405B: 78). Avalike arutelude teemaks mõisnike ja talurahva omavaheline suhe praegu siiski ei ole. On oluline jälgida, mis seoses ühed või teised kogemused aktualiseeruvad ja kuidas end jutustamise ajal nende kogemustega suhestatakse. Sotsioloog Aili AarelaidTart kasutab siinses kontekstis kultuuritrauma mõistet: see puudutab nimelt ühiskonda üldiselt, millest lähtuvalt saab vaadelda üksikisiku traumat, mitte vastupidi. Eeltoodud näites on indiviiditasandi trauma lähedaste surm ja alles seejärel lähedaste kaotust põhjustanud ühiskondlikud olud. Esile kerkib küsimus, kuidas suhestuvad omavahel individuaalne ja avalik-ühiskondlik tasand. Ühtlasi võib märgata, et traumaga seostatavad sündmused ei ole üksikud, teistest aktuaalsetest teemadest sõltumatud hetked või olukorrad.

Avalike arutelude vaatepunktist juhib kirjandusteadlane Eneken Laanes tähelepanu sellele, et trauma kontseptsioonist lähtudes (s.o kasutades rahvusvaheliselt tuntud traumakeelt), saab "rääkida vägivaldsetest ajaloosündmustest üle kogu maailma ja mis on rahvusvaheliselt arusaadav" (Laanes 2017: 243). Tõenäoliselt on selles kontekstis oluline LaCapra mõiste "struktuuriline trauma", mis viitab samalaadsetest kogemustest lähtuvatele tunnetele (nagu kaotusvalu vms), eeldamata ajaloolis-kultuurilise konteksti tundmist. Nii tuleb esile pigem trauma psühholoogiline kui ajalooline tahk. Samas aga ei saa traumaatilistest kogemustest kõnelda nõnda, et need oleksid päriselt lahutatud ajalooliselt konkreetsetest ja lokaalsetest sündmustest. Räägitakse ju konkreetses aegruumis toimunud asjadest ja mis veelgi olulisem, rääkimisel kasutatakse traditsioonilisi jutustamisvõtteid. Sel põhjusel võib küsida, mil määral hakkab rahvusvaheline trauma keel kujundama teemasid, millest kohalike kogemuste kohta räägitakse? (Mäletatavasti peituvad tänapäevase trauma keele juured Põhja-Ameerika kultuuris ja holokausti teemas? Seega näiteks: kuidas holokaustist kõneldav loob raame stalinlikest vangilaagritest kõnelemisele vms.)

On võimalik, et massimeedia vahendusel hakkab traumakontseptsioonist lähtuv rahvusvaheliselt tuttav esitusviis kujundama ka kultuursidusaid ju- 
tustusi. Samas aga ei pea eeldama, et mõjusuhted on üheselt eeskuju pakkuvad, liikudes professionaalsetelt ja massimeedia tekstidelt rahvapärasele eluloo jutustamisele. Jutustajate, kogukondade ja ühiskonna (avalikkuse) valik seisneb selles, mil määral oma (traumaatilist) kogemust tahetakse ja tahtmise korral osatakse suhestada kultuuriülese trauma keelega. Ühtlasi ilmneb, et elulugudes esitatav traumakogemus (olgu individuaalne või laiemas ringis või ühiskonnas üldiselt arutletav) seostub teiste, jutustaja enda vaatepunktist oluliste sündmuste ja olukordadega. Analüüsi seisukohast on sel põhjusel otstarbekas vaadelda traumaatilise kogemuse paigutumist jutustuses esitatud teiste kogemuste suhtes.

\section{Trauma piiritlemine eluloos}

Trauma uurimisel on võimalik kasutada nii teemaintervjuude abil loodavat allikmaterjali (mille loomise aluseks on traumateooria) kui ka olemasolevaid tekste (nagu ka antud juhul, kus elulood ei ole kirjutatud trauma uurimise eesmärke silmas pidades). Kuidas piiritleda traumat viimati mainitud juhul? Ka siin võib abiks võtta traumateooriast pärit seisukohti, mida saab kohandada elulugude lugemise ja analüüsimise skeemiks.

Sotsioloog Aili Aarelaid-Tart (2006: 41-48) määratleb kultuuritraumat, võttes arvesse nii sündmusi kui ka neist kõnelemist. Täpsemalt on kultuuritrauma seotud murrangut tekitanud ajalooliste ja sotsiaalsete sündmustega. Neid murranguid kogetakse ühiskonnas negatiivsetena ja seda ka teadvustatakse: nende muutuste üle peetakse aru. Nii hõlmab kultuuritrauma sündmuste ja kogemuste kõrval ka ühiskonna ja jutustaja sotsiaalse positsiooni muutustega seotud arutelu. Sotsiaalteadlased rõhutavadki kultuuritrauma sotsiaalset konstrueeritust, kus olulist rolli mängib identiteet: "Kultuuritrauma on kognitiivne konstruktsioon, mis väljendab identiteedi kriisi" (Aarelaid-Tart 2016: 43). Selle konstruktsiooni mõistmiseks on vaja jälgida traumat esile kutsunud tõsielusündmuste ja trauma väljendusviiside omavahelist seotust (Debs 2012). Ühiskonna trauma uuringutes on seega esil sündmuste ja nendest kõnelemise vahelised seosed, kus traumale ligipääsemiseks lasub uurimisfookus identiteedimuutustel. Tuuakse ka esile trauma mõju tugevust, mistõttu seda on raske kontrolli all hoida ja sellest päriselt jagu saada on peaaegu võimatu (LaCapra 2014: 41).

Kirjandusteaduslikes käsitlustes on esile tõstetud trauma väljendusviisid nii trauma läbitöötamisvahendi (nt väljaelamine, leinamine) kui ka kujundkeelena. Lähtepunkti pakuvad ühelt poolt Põhja-Ameerika kirjandusteaduses 20. sajandi lõpul esilekerkinud teemad ning teisalt Sigmund Freudi ja Dominick LaCapra 
tööd (Kirss 2002: 1870). Põhja-Ameerika kirjanduskontekstist johtub näiteks see, et Tiina Kirss, analüüsides 1944. aastal Läände põgenemise teemalist pagulaskirjandust, loob sellele paralleele holokausti-tekstidest (Samas). Kirjandusteoste analüüsis kerkivad esile traumaga seotud mõisted (sh "traumanarratiiv"), trauma sümbolid ja muud esitusviisid. Nii kirjutab Maarja Hollo (2016: 85): "Tartu-romaanide tsüklit kui traumanarratiivi võib seetõttu vaadelda katsena jõuda mineviku väljaelamise ja läbitöötamise kaudu ideaalse mäletamiseni [---]". Ilukirjanduslikes tekstides on traumakogemus teadlikult ja kujundkeeles tihendatult esitatud. Sellisena erineb ilukirjandus nii sotsioloogide kui ka folkloristide allikmaterjalist, kus tõsielu kujutamine on märkimisväärselt vahetum, spontaansem ja lõdvema struktuuriga. Elulood sobituvad aga nii kirjandusteaduslike, sotsioloogiliste kui ka folkloristlike uurimisviisidega.

Kirjandusteadulikes elulooanalüüsides tuuakse esile nii trauma keel kui ka Eesti ajalooga seotud sündmuste kujutamisviise. Näiteks Tiina Kirss esitleb trauma sümbolite või märkidena selliseid nähtusi tekstis nagu lahkumine, põgenemine, paat tormisel merel, aga ka teksti niisuguseid tasandeid nagu nostalgiline kodumaapilt, tegelaste passiivsus, unenägude tähenduslikkus jms (Kirss 2002: 1874-1875). Eluloouurimise kontekstis on erilist tähelepanu pälvinud Imbi Paju film “Tõrjutud mälestused” (2005). Just sellele filmile tuginedes on Leena Kurvet-Käosaar ja Eneken Laanes analüüsinud trauma keele (või ka mäluvormide $)^{14}$ muutumist Eestis. Mõlemad autorid märgivad, et Paju käsitlus stalinlikust vangilaagrist erineb märkimisväärselt nõukogude võimu repressioonide varasemast kujutamisest, kuna Paju asetab oma loo teadlikult traumateooria raamidesse (Kurvet-Käosaar 2008: 136-137; Laanes 2017: 243). Laanes selgitab: ühelt poolt sisaldab see traumakogemuse seostamise ohvriks olemise ja moraalse andekspalumise ning andestamise teemaga. Teisalt toob selline kujutamisviis kaasa kultuuriülesuse, sest loo jutustamisel kasutatakse niisuguseid sümboleid ja kujutamisviise, mida tuntakse üldinimliku kannatusena ja mis ei eeldata traumakogemust põhjustanud ajaloolise tausta tundmist (Laanes 2017: 244). Imbi Paju esitatu on üles ehitatud (auto)biograafilisele jutustusele ja loob sellisena paralleeli Eesti elulugude kogus (EKLA f 350) olevatele käsikirjalistele tekstidele, sh ka nende põhjal avaldatud elulugude kogumikele "Me tulime tagasi" (1999), "Eesti rahva elulood" I-II (2000-2003). ${ }^{15}$ Leena Kurvet-Käosaare käsitluses põimuvad ajaloolise trauma kontseptsioon ja Freudi psühhoanalüüsist lähtuv trauma (Kurvet-Käosaar 2008: 137). Ka Imbi Paju filmi analüüsib ta ajaloolise trauma vaatepunktist (Samas). Kuigi ka Eesti elulugude kogu tekstid on vaadeldavad ajaloolise trauma vaatepunktist, erinevad need põhimõtteliselt Paju käsitlusest: elulugudes ei keskenduta mitte niivõrd traumakogemusele ja vägivalla ohvriks olemisele, kuivõrd sellega toimetulekule. Nii on elulugude valdav sõnum Kurvet-Käosaare järgi see, et 
režiimi tekitatud olukorrad ei suutnud inimesi vaimselt murda (Kurvet-Käosaar 2008: 140). On omaette küsimus, kas traumaatilise kogemusega toimetulek on samuti vaadeldav traumateooriast lähtudes või mitte. Siinkohal on oluline siiski jutustaja enesemääratlus, kus traumauuringute seisukohast on jutustaja vägivalla ohver, elulugudes see aga nii ei pruugi olla.

\section{Traumauuringud ja folkloristika}

Mida võiks pakkuda mitmedistsiplinaarsesse traumauurimisse folkloristlik elulooanalüüs? Kui sotsioloogid ja kirjandusteadlased vaatlevad enam institutsionaalsetes kogukondades või avalikkuses toimuvaid arutelusid, siis kõik traumakogemusega seotud teemad, lähenemis- ja esitusviisid ei saa olla avalikkuses esiplaanil. Ja ka vastupidi - kõik avalikkuses arutelu all olevad teemad ei ole samavõrra olulised individuaalsel või väikeste rühmade tasandil. Folkloristlikust vaatepunktist osutuvad oluliseks tõsielule tuginevate lugude indiviiditasand, kultuurisidus jutustamine ja lugude varieerumine. Millisena avaldub traumakogemus individuaalsel tasandil eluloos, mis ei ole otseselt traumanarratiiv ja milles ei keskenduta traumateoorias olulistele aspektidele (vägivalla ohvriks olemine, andekspalumise ja andestamise teema)? Kui vaadelda traumat ühiskonda tervikuna mõjutavate sündmuste seisukohast (riigipööre, sõda, küüditamine, looduskatastroof vms), siis avalikes sõnavõttudes ei pruugi avalduda need aspektid, mis tulevad esile eluloos. Indiviidikesksusele lisaks on näiteks lapse vaade küüditamisele ja sõjale erinev tema vanema või vanavanemate omast. Liiati hõlmab ühes ajahetkes koostatud elulugu erinevatel aegadel välja kujunenud tuumlugusid ${ }^{16}$ ja nende kommentaare. Võttes analüüsi keskmeks trauma kontseptsiooni (eriti selle seotuse ühiskonnas ja identiteedis aset leidnud muutustega), võimaldab folkloristika analüüsida jutustajast lähtuvat vaadet ja esitust. Tekstianalüüsis on oluline määratleda seos traumaatiliste kogemuste ja eluseikade kujutamise vahel. Nii nagu ühiskonna tasandil käsitletav kultuuritrauma ei ole indiviidide traumakogemuste summa, ei ole ka individuaalse loo traumakogemus üldise traumakontseptsiooni peegeldus või selle minivorm. Nagu folkloristikas, nii on ka kirjandusteadlaste uurimisfookuses peaasjalikult indiviiditasand. Ent erinevus seisneb siin traumanarratiivi moodustumises: eluloo jutustajakesksus ei võimalda tõsielukonkreetsusest eemalduda kujundliku üldistuseni (mis ei välista loomulikult elutarkuse väljakoorumist).

Traumaatiliste kogemuste puhul on tegemist teabe kogunemisega aju teatud ossa, mis omakorda annab endast märku traumaatilisena kogetud sündmuste meenutamisel (Markowitsch 2002). Elulugudest võib selliseid tahke ära tunda 
niisugustest lisandustest, nagu on kirjutanud 2017. aastal Eesti elulugude kogumisvõistlusele saadetud loos: "Selle peatüki kirjutamine on mulle väga ebameeldiv, tuli elustada mälestused" (EKLA f 350, 182/2017).

Selles mõttes ei ole trauma pelgalt kannatuste esitamise viis, vaid ühendub oma esialgse tähendusega - kehalise kannatusega - ka jutustamise ajal. Seega, ühelt poolt pakub üksiklugude analüüs võimalusi näha traumaatilist kogemust nii sündmuste kui ka jutustaja emotsionaalse seisundi tasandilt, ja seda tema enda, mitte avalikkuse vaatepunktist. Teisalt tuleb siin mängu folkloristika üks põhikontseptsioone - varieeruvus. Folkloristikas pole põhjust käsitleda üht elulooesitust selle loo ainsa ja lõpliku kujuga, pigem on tegemist sama loo ühe esitusversiooni ehk variandiga. Kui sama jutustaja esitab oma lugu mitmeid erinevaid kordi, võib jälgida, kuidas tema hoiak ja emotsionaalne suhe jutustatavatesse sündmustesse kas püsib või muutub. Esitusolukorra analüüs omakorda pakub teavet selle kohta, mis need muutused või muutumatuse esile kutsub. Sama loo korduvate esituste (variaabluse) võrdlemine osutab ühtlasi traumakogemuse dünaamilisele loomusele. Seega on folkloristika sotsioloogiliste ja kirjandusteaduslike uuringutega võrreldes esituskesksem (kujutatava nähtuse ja tekstikesksuse asemel).

Elulugudes nähtavale kerkivad (kultuuri)trauma teemad ei pruugi lähtuda samadest teguritest, mis iseloomustavad avaliku arutelu tekkimist. Näiteks Austraalias elav 1935. aastal sündinud eestlanna arutleb oma eluloos andekspalumise ja andeksandmise üle (EKLA f 350, 818: 8). Siin meenub talle üks seltskonnas peetud vaidlus teemal, kas Austraalia peaminister peaks andeks paluma aborigeenidelt selle eest, mis minevikus on toimunud. Tema oli seekord seisukohal, et jah, kuna see harutaks lahti mõnedki suhete umbsõlmed. Ent eluloo seisukohast ei ole tähtis mitte niivõrd Austraalia ministri poliitiline samm, kuivõrd jutustaja enda arvamus andeks palumisest ja andestamisest isiklikes suhetes. Nimelt näitab ta, et enda ellu ja suhetesse ta andekspalumise ja andeksandmise tähtsust ei osanud tookordse poliitilise arutelu käigus sisse mõelda. Selleni jõudis ta Luule Viilma raamatu abil. Nii võib elulugudest (mis on ju küll konkreetsel ajahetkel jutustatud lugu) ikka ja jälle leida jälgi tunnete ja arusaamise kujunemise pikaaegsest protsessist, kus ka avalikel aruteludel on oma osa. Kui siia veel lisada näiteid, siis kirjutab üks 1927. aastal sündinud soomlanna Talve- ja Jätkusõjaga seoses, et sõja ajal ei teadnud soomlased Hitleri julmusest juutide vastu, ent kui pärast sõda sellest kuuldi, häbeneti oma sõjaaegseid positiivseid tundeid sakslaste suhtes. Aja möödudes on ta aga jõudnud arusaamiseni, et julmust võib kõikjal ja kõigiga seoses kohata (Sota-aika: 12). Analoogiliselt arutleb oma eluloos 1936. aastal sündinud eestlanna: "Ma ei teadnud midagi juutide koonduslaagritest, mis, nagu hiljem olen kuulnud, asunud meile kaunis lähedal Kunda ümbruses. Kas ei teatud 
nendest või ei räägitud lapse kuuldes.” Ent teadasaamise etapid selles loos on omamoodi kõnekad. Jutustaja selgitab, et nõukogude ajal kõneldi "sakslaste kuritegudest", ent inimesed võtsid seda kui nõukogude propagandat, sest ka 9. märtsi pommitamist esitati kui "sakslaste kätetööd”. Ent viimane väide mõjus kummaliselt: "Juurdlesin tol ajal palju selle kallal, miks pidid sakslased oma sõdureid pommitama. Ja jõudsin järeldusele, et ju see ikka nii ei olnud" (EKLA f 350, 1726). Et sõda teeb inimesed julmaks, selle üle arutleb 1914. aastal sündinud mees nõnda: vaevalt tehti Nõukogude Liidus nii suurt ülekohut teiste rahvaste vastu kui tehti juutidele nende kodumaal. Siit omakorda jätkab ta arutelu tänapäeva-poliitikast lähtudes - juudid on ajanud palestiinlased ära oma kodumaalt ja kohalik viha aina kasvab (Sota-aika: 894). Sellistes arutelupunktides (avalik versus isiklik andekspalumine; julmus ja vägivald rahvaste vahel kui suundi muutev protsess; ühe või teise võimu tehtud kahju suurus jms) ilmneb dialoog privaatse tasandi eluloo ja avalike diskursuste (nt ilukirjanduslike, massimeedia vms avalike tekstide) vahel. Siit ka järeldub, et kuigi jutustajad tunnevad ja teavad erinevate tasandite teemasid ja lähenemisviise, ei kandu avalikkuses domineeriv trauma keel kui mäluvorm üheselt individuaalsele tasandile üle. ${ }^{17}$ Erinevad tõlgendused ja lähenemisviisid käivitavad ka rahvapärastes jutustustes arutelu, kuid otsest avalike seisukohtade ülevõtmist ei toimu. Tähtis on ka rõhutada, et nagu avalik arutelu nii ka rahvapärane mõtteviis ei ole seesmiselt ühtne.

\section{Kaks elulugu trauma vaatepunktist}

Analüüsitavate lugude valik on ühelt poolt inspireeritud Leena Kurvet-Käosaare ja Eneken Laanese käsitlusest, milles nad näitavad veenvalt Imbi Paju “Tõrjutud mälestuste" (2005) uudsust eesti kultuuris: stalinliku vangilaagri kogemus naise vaatepunktist, kultuurideülese trauma keele kasutus (mis seostub selliste märksõnadega nagu "ohver", "andekspalumine” ja "andestamine”, järelmälu ehk sündmuste läbielamise toime järgmisele põlvkonnale). Ka valitud elulugude jutustajad on naised, kelle lood kajastavad samu ajaloolisi sündmusi ning sellest lähtuvaid läbielamisi. Ka need lood on jutustatud 20. sajandi lõpus, 21. sajandi alguses. Erinevus seisneb mõistagi jutustajate vaatepunktide mitmesuses, mis on olemas filmis, ent puudub elulugudes, jutustajate monoesitustes. Olulisena tõstatub aga küsimus, milline on siin käsitlevate lugude trauma keel (kui kasutada traumateooria mõistet).

Üks jutustajatest, 1923. aastal sündinu, on metsavendadega suhtlemise tõttu nõukogude võimu poolt vangistatud. Meenutagem, et ka Imbi Paju filmi peategelased olid vangistatud samal põhjusel (Laanes 2017: 241). Teise eluloo 
autoriks on 1912. aastal sündinud naine. Tema lugu vahetut vangilaagri kogemust ei kajasta. Samas ulatuvad tema kogemused 20. sajandi esimese poole sõdade aega, mistõttu on huvitav jälgida, kuidas tema käsitleb võõrvõimudega seotud tagasilööke (vangistusi, küüditamisi), aga ka majanduslikke vms argielulisi muresid nii enne kui pärast Teist maailmasõda. Esmalt mainitud 245-leheküljeline käsitsi kirjutatud lugu on dateeritud 1997. aasta 24. veebruariga ja on saadetud samal aastal kultuuriloolisse arhiivi elulugude kogumisvõistlusele "Minu ja minu lähedaste saatus ajaloo keerdkäikudes" (EKLA f 350, 444). Teise, 47-leheküljelise arvutikirjas loo on 2008. aasta kevadel "Memme jutu järgi" kirja pannud tütar ning saatnud samal aastal elulugude kogumisvõistlusele "Eesti Vabariik 90" (EKLA f 350, 2414).

Nende lugude valik on tähenduslik ka folkloristlikust vaatepunktist: nimelt olen mõlema autoriga kohtunud ja nendega elulooteemadel vestelnud. Esmalt tutvustatud loo autoriga kohtusin Patareis, kui seal enam vanglat ei olnud. Seal toimus Rutt Hinrikuse koostatud vanglateemaliste elulugude kogumiku "Võimas ja sünge Patarei" (2007) esitlus Tallinnas. Meie jutuajamine piirdus vanglateemaga. Ühtlasi on sama autor olnud aktiivne Eesti Rahva Muuseumi korrespondent: ta on ajavahemikus 1994-2005 saatnud muuseumile kaastöö 25 temaatilisele kogumisvõistlusele (vt nimestikku Tael 2006: 134). Siinses artiklis on kasutatud kahte neist: "Elu nõukogude vangimajades ja -laagrites" 1999 (KV 890) ning "Elu nõukogude ajal” 2001 (KV 983). Erinevalt elulugudest põhinevad Eesti Rahva Muuseumile saadetud kaastööd uurijate esitatud küsimustikul, mis mõjutab jutustaja teksti ülesehitust, teemasid ja sõnakasutust. Sellegipoolest on kõigis nimetatud käsikirjades kattuvaid osi, mida oma uurimuses käsitlen tuumlugudena. Teise loo autoriga kohtusin 2008. aasta 5. juunil tema kodus, kus intervjueerisime teda koos Rutt Hinrikusega. Sellest kohtumisest saan vestlusaruandele lisaks kasutada ka salvestatud intervjuud, mis hõlmab põhiliselt jutustaja lapse- ja noorpõlve. Need kohtumised loovad arhiivi saadetud elulootekstis sõnastatud tuumlugudele kontekste - see on oluline, kuna kirjaliku eluloo ja vestlustes esitatud tuumlugude sidusus ei ole täpselt seesama. Esituste võrdlemise kaudu saab jälgida nii loo varieeruvust kui ka seda, mis tegurid ühe või teise tuumloo meenutamise esile kutsusid, kuidas muutuv esituskontekst lugu kujundab.

Esimene lugu. 1923. aastal sündinud naise jutustus on osalt kronoloogiline, osalt kõrvale- ja tagasipõikeid pakkuv. Autor alustab lapsepõlvekirjeldustega Läänemaa külas, jätkab kooli ja ametiõppe teemadel Haapsalus ja jõuab 18. leheküljel enda arreteerimise ${ }^{18}$ kirjelduseni 1948. aastal "metsavendadega sidemete pidamise pärast". Siin peab ta minema ajas tagasi, et selgitada, miks ta metsavendadega suhtles. Tegemist on endas veel selgusele jõudmata armastuses, tugevas kiindumuses noormehe vastu, kes oma sõjaaegsete valikute tõttu 
sattus metsavendade rühma. Arreteerimise ja vangistus- ning laagriperiood (1948-1955) mahub 32 leheküljele 245-st ning on olukordi fikseeriv. ${ }^{19}$ Muude eluperioodide kirjeldused on eluloojutustuses seevastu läbi põimitud mitmete hargnemiste ja arutluspausidega.

Iseloomulik sellele loole on, et erinevates seostes tuleb taas ja taas jutuks lapsepõlve- ja noorusaeg. Trauma seisukohast on need tagasivaated tähelepanuväärsed, sest neis hakkavad välja kooruma tõed, mis on aidanud jutustajal toime tulla vangistuse ja sellele järgnenud perioodiga. Ta siseneb kihthaaval oma pere tähendusringidesse: kui esmalt annab ta lugejale pildirikka vaate keskkonnale, kus elulootegevus toimub ("Mu kodumaja oli õlgkatusega, see asus ühe katuse all rehetoa ja rehealusega, rehealuse otsas oli aganik", lk 1), siis uutes juturingides süveneb ta peretraditsioonidesse, tutvustab kombeid, harrastusi, vaatleb laste omavahelisi suhteid jne. Niimoodi üha sügavamale kaevudes jõuab ta välisvaatleja pilgul esitatud sündmustest ja tegevuspaikadest iseenda kui isiksuse avamiseni. Üks olulisi arutluskäike on see, kuidas on temani jõudnud halastuse ja armastuse teema ning kuidas on temas kujunenud empaatiavõime. Talulapsele omaselt leidub selles arutluses palju seiku inimese suhtumisest loomadesse: kuidas ta ise karjas käies loomadega hakkama sai, millisena nägi ta voorimehi hobustega toimetamas. Neis kirjeldustes arutleb ta nii enda käitumise kui ka selle üle, mida ta teiste puhul tähele pani, ja osutab tõikadele, miks ta on hakanud nende tavaliste argieluliste asjade üle järele mõtlema. See arutelu kulmineerub loo lõpus, kus ta väidab: "Pikki aastaid olid mu elus parimad aastad nagu „kiskjalik võitlus olemasolu eest“ ja sellest saadud jäljed on jäänud kogu eluks" (lk 230). Sama väljendit - "kiskjalik võitlus" - kasutab ta Eesti Rahva Muuseumile saadetud kaastöös: “Tugev elutahe ja nagu kiskjalik võitlus olemasolu eest aitasid mul kanda rohkem kui kuus aastat kestnud vangipõlve ja jõuda tagasi kodumaale" (KV 890: 203). Loomakujundite kasutus (siin "kiskjalik võitlus", ent nii selles loos kui ka üldiselt kasutatud "loomavagunid") on üks rahvapärase trauma keele erijooni, mida vangilaagrilugudes silmahakkavalt palju kohtab (vrd Jaago 2014: 14-15). Ent laagriepisoodide kirjeldusest tuleb tsivilisatsiooni piir enda ja "teiste" vahel esile ka muus sõnavalikus, näiteks vangidega toimetati kui esemetega - neid "sorteeriti" (lk 42) või erialasele tööle saamise järel muutus elu "tunduvalt inimväärsemaks" (lk 46). Loomakujunditega seoses eristub siinses eluloos kaks tasandit. Kui empaatia kujunemisel kirjeldab ta inimese suhtumist looma ja sellega ühenduses inimeseks kasvamist, siis vangistust saab ta kultuuriomaselt kujutada inimese ja looma vastandamise kaudu. Esimesel juhul tuleb esile vastutuse, kannatlikkuse ja loomi hoidva suhte kujunemine jutustaja elu vältel. Teisel juhul saab ta ebainimlikuna kogetud olukordi kirjeldada kui elu loomade maailmas (elajalik keskkond, kiskjalik käitumine, loomadele mõeldud vagunid). 
Enda kui isiksuse arenguloo teine liin (halastuse ja empaatia kujunemise kõrval) seostub episoodidega, kui ta kirjeldab pikemalt oma ema ja isa. Ema kirjeldustes tuleb esile tema kannatlikkus, oskus raskustega toime tulla. Isa kirjeldusse kuuluvad emotsionaalselt koos läbitud hetked: "Mulle meenub väga ilus talvine õhtu, kui sõitsin isaga linnast maale läbi lumise metsa. Kuu säras taevas ja ümbrus tundus muinasjutuna." Sel teekonnal isa rääkis oma minevikust ja laulis "vanu tsaariaegseid laule", mille sõnad autor ka oma loosse paigutab (lk $241 \mathrm{jj}$ ). Isaga seostatav laulmise ja muusikateema on selles loos võtmetähendusega olukordades, mis on jutustajast minategelasele rasked. Ilmneb, et laulmine võimaldab neis olukordades omal moel toime tulla ja end väärikalt tunda. Ema näikse aga olevat jutustaja moraalse jõu allikaks: "Olen oma emale hauapõhjani tänulik selle hoole ja armastuse eest, jõu eest mitte kokku variseda eluraskuste ja karmi saatuse ees ..." (lk 109). Neid omadusi ja oskusi, mille kaudu ta ema kirjeldab, ei kanna ta endale otseselt üle. Kuid tugev vaimne seos emaga ja ema vastupidavusvõime imetlemine haakuvad ta enesekirjeldusega sellest, kuidas ta ise on kõikidest raskustest üle saanud. Episoodis, kus ta kirjeldab inimesi, kellega ta koos sõjatribunali otsuse ettelugemist ootas, jõuab ta enesekohase kokkuvõtteni: "Pean saatust tänama, et mul oli eriline jõud olla igasugusest olukorrast üle." See kokkuvõte sünnib ühelt poolt võrdluses, kus ta kirjeldab süüdistust ootavaid kaaslasi (nende hulgas oli rusutuid, "üks mees nuttis"). Teisalt vaatab ta 75aastase naisena tagasi endale, kes 25aastasena sattus äärmuslikku olukorda. Sellist hirmutava tulevikuga silmitsi olevate inimeste kirjeldusi kuulsin ka siis, kui jutustajaga 2007. aastal Patarei ouel ringi liikusime. Need kirjeldused on napisõnalised, emotsiooni- ja hinnanguvabad, ent ometi mõjukad. Samalaadset esitusviisi on täheldanud ka Tiina Kirss, analüüsides ühe naise vangistuskirjeldust: "Helmes Tungla eluloo koestik koosneb lühikestest, lakoonilistest lausetest, seda eriti Siberi-elu kirjeldavates lõikudes" (Kirss 2003: 228). Ühtlasi viitab jutustaja siin saatusele ("pean saatust tänama”). Selles kontekstis ilmneb saatus kui kaasaantu, mis võimaldab jutustajal-minategelasel igas olukorras toime tulla. Avaliku diskursuse tasandilt näeb Leena Huima saatust Eesti elulugudes kui stereotüüpi: see on "võõra, välise jõu ettemääratud elukäik, mida võib teatud määral tublidusega trotsida" (Huima 2002: 73). Huima artikkel tugineb Eesti elulugude kogu tekstide toimetatud ja publitseeritud versioonidele. Selle jutustaja käsikirjast aga ei ilmne, et "saatus" piirduks elukäiguga. Pigem sisaldab "saatus" nii elukäiku kui ka selle kujundamiseks kaasa antud võimaluste pagasit.

Rahvapärase jutustamise trauma keele erijoonena tooksin esile nimelt napisõnalisuse ja mõjukuse samaaegsuse. Inimest vapustanud olukorra kirjelduse lakoonilisus võib olla tingitud paljudest asjaoludest, kuid ilmselt on üks neist ka läbielatud olukorra enda loomus. Näiteks sotsiaalpsühholoog Harald Welzer 
on juhtinud tähelepanu traumaatilistest kogemustest jutustamise lahknevusele tavalistest seikadest jutustamisega võrreldes. Traumaatilise sündmuse või olukorra läbielamisega kaasnevad emotsioonid kas pärsivad või toetavad sellest jutustamist, mistõttu läbielamist iseloomustav seisund on tajutav ka jutustuses (Welzer 2000: 55-56). Meeldejätmise hetke mõju sellele, mida meelde jäetakse, toetavad ka mälu ja meenutamisega seotud uuringud: "Iga sündmust või fakti jäetakse meelde iseloomulikul viisil, sõltuvalt sellest, milline oli vaimne tegevus meeldejätmise hetkel" (Tulving 1994: 48). Mälestustele rajaneval jutustamisel võib märgata meeldejätmise olukorraga seotud pöördeid. Näiteks 1905. aasta mõisate põlemisega seoses kirjeldab üks mees pikalt, kuidas mõisa jõuti, kirjeldades seda kõike ise kohal olevana. Siis toimub äkki tema kui kohalolija tunnistuses pööre: ta ei mäleta, kuidas ta järsku sattus lõhkumiste, purustamiste ja tulekahju keskele, kusjuures ta ei kirjelda end kaasosalisena: ta ei eita seda, et ta oli seal ja oli üks mõisa põletajatest, ta nimelt kirjeldab seda kui filmi, mida ta näeb, aga milles ta ei osale (EKLA f 172, m 6, 1 116-117). Samalaadset vastuolulist kirjeldusviisi (ühelt poolt äärmuslikud olukorrad, teiselt poolt lakooniline, emotsioonideta esitus) võib kohata Leningradi blokaadi vahendavates elulugudes. Näiteks kirjutab 1924. aastal Leningradi eesti peres sündinud naine esimese sõjatalve argielust kodulinnas (EKLA f 350, 1857). Ta kasutab lihtlauseid, kus faktiteabe kõrvale ei mahu ühtki meelolu või tundeid kirjeldavat seika: "Vett tõime Neeva jõest. Jõgi oli külmunud. Aga veeauk vee võtmiseks oli alati lahti. Selle augu lahti hoidmise eest hoolitsesid madrused. [---] Ümber veeava olid ka inimlaibad. Tõmmati laip eemale ja järgmine inimene võttis vett. Neid laipu oli kohe päris palju. Vee järel käidi, kes ämbriga, aga suurem osa teekannudega või mõne kastruliga." Loo lõpus avab ta oma tunded: "Need mälestused on mulle väga rasked. Seda jutustades elan ma seda kõike uuesti läbi.” Kuid tähelepanuväärne on, et emotsioonid ja olustiku ning sündmuste kirjeldused samas kujutluspildis ei põimu.

Siin analüüsitava jutustaja loos tuleb korduvalt esile lapsepõlvekodust ja perest lähtuvate väärtuste teema. Nendeks väärtusteks nimetab ta töökust ja kokkuhoidlikkust (lk 233-240), mida õpetati kodus ja mida oli vaja vanglaperioodil, et tulla toime kasinate võimaluste maailmas, ja ühtlasi paneb see teda arutlema 1990. aastate Eesti elu üle. Oma elukogemuse ja tõekspidamiste esitamises jutustamisaegsete olukordade hindamisel ilmnevad ühtlasi ka jutustaja hoiakud avalike aruteluteemade suhtes. Näiteks sajandi lõpul esile kerkinud varalise kihistumise teema, kus osa inimesi on "nii vaesed, et ei suuda eluga toime tulla". Enda kohta neis samades ühiskondlikes raamides aga ütleb ta, et tema saab hakkama tänu elus karastumisele, samas kus "varem elu poolt hellitatud inimesed" ei oska oma elu korraldada, seda "tihti ka saamatusest" (lk 195). Lisaks toimetuleku probleemidele arutleb ta 1990. aastate poliitika 
mitmepalgelisuse ja ühiskonna moraalilanguse üle (lk 193-195, 233-224). Ilmneb ka, et ta ei tunneta Eesti Vabariigi moraalset tuge, sest küüditamistele ja vangistamistele kaasa aidanud või sellest kasu lõiganud inimesed elavad ühiskonnas külg külje kõrval teistega, nagu poleks midagi olnud: "Selle koletu teo väljamõtlejaid, organiseerijaid ja täideviijaid nagu poleks olnudki" (lk 227). Oma pere näitel toob ta esile nii enneaegsed surmad kui ka pereliikmete lahutamise üksteisest ja kodust. Oma isatalu uute, nõukogudeaegsete elanike suhtes ta sõbralikkust üles ei näita. Kui kogukonnatasandi kirjeldustes on esil see, kui palju kahju inimestele tehti, siis tema enese-pildis langeb raskuspunkt siiski hakkamasaamisele: "Püüan võimalikult kohaneda igas olukorras ja keerulistes olukordades omal jõul välja tulla, kellegi teise peale ei ole mul loota, ainult iseendale" (lk 230). Nii on ootuspärane, et tema eluloo üks kesksemaid aruteluteemasid ongi tasakaalu otsimine endas, abiks lapsepõlvest kaasa antud põhiväärtused ja elu vältel kogetu. Kõige selle aluseks on "Jumala 10 käsku“ hoolimata sellest, et mitte igas eluhetkes ta seda järgida ei saanud. Kirjeldatud aruteludes avaldub jutustaja minapilt, mida kirjalikuna loodud eluloojutustuse puhul on uurijad kirjeldanud kui "kujuteldavat mina" (Pöysä 2009: 46). Eluloojutustaja ei saa vastuollu minna tegelikkusega, küll aga saab ta oma lugu kontrollida ja kujundada, ilma et keegi tema minapilti kirjutamisprotsessis vaidlustaks.

Teemade korduvuses, kus igal uuel esitusringil lisandub uut teavet, võib omakorda näha traumaatilise kogemuse jälgi. Neis taasjutustatavates episoodides tegeleb ta oluliste seikadega, mis tema elu ühel või teisel etapil on teda sundinud endasse vaatama. Olgu selleks siis karjusekogemus, mis andis jutustajale ainet enda empaatia kujunemise jälgimiseks, vangistus ja hakkamasaamine pärast vangistust, mis pakkus võimalust mõtiskleda ka enda jõuallika - pereväärtuste ja vanemate - üle. Ühtlasi nähtub, kuidas karjusekogemus põimub vangikogemusega, kasvades sealt edasi aktsepteeritavaks minapildiks, eluloo sõnumiks.

Ajaloolistest ja sotsiaalsetest situatsioonidest lähtuvate kogemuste kõrval on selles loos samalaadselt kujutatud ka üht isiklikku traumat: laste omavahelise mängu käigus vigastas vend kogemata tema silma. Vigastatud silm tuleb eluloos esile mitmel korral: neiuna tekitas see alaväärsust, pere raames nukrust õnnetuse pärast - seda nii haiget saanu kui selle tekitaja pärast, vanas eas tuleb vigastatud silm jutuks terviseprobleemina. Ta rõhutab mitmel korral ja mitmes seoses, et ta ei ole vennale selle õnnetuse pärast pahane. Eluloo seisukohast on aga oluline see, kuidas avaneb traumaatilise kogemuse mitmetasandilisus ja pikaaegne kujunemislugu. Millegi korduv ja erineva nurga alt käsitlemist leidev olukord on taas vihje trauma keelele eluloos. Võib kaaluda, kas vigastatud 
silma teema ei põimu ositi noorusaja armastusloo kuhtumisega sel määral, et ka viimast võiks käsitleda traumakogemusena. Kui seda teha, siis tuleb märkida armastusteema ilmnemise eripära. Ta ei arutle selle üle pikalt ja korduvalt, kuid väljendab selgelt kaotuse valu. Võib mõista, kuidas argielulised inimestevahelised suhted põimusid sõjaajast ja vangistusest johtuvate tingimustega: nooruses väljavalitu sattus nõukogude võimuga vastuollu sel määral, et kaotas oma elu; vanglaarmastatu oli pärit teisest kultuuriruumist ja nende teed ei kattunud väljaspool vangalapiire. Teisalt võiks jutustaja suhtekogemuse traumaatilisust näha tema enda elukäigu võrdluses vanemate omaga. Ta kirjeldab oma lapsepõlveperet ja vanemaid kui terviklikku ja toimivat kooslust, mida ta sõjaaegsetes ja -järgsetes tingimustes ise luua ei saanud.

Mis viitab traumakogemusele selles loos? Esmalt kirjeldusviis, kus jutustaja tuleb mõne teema juurde ikka ja jälle tagasi: pereväärtused, vigastatud silm. Kui esmapilgul ei saa pereväärtusi traumaga siduda, siis süvenedes ilmneb nende tähendus traumaatiliste sündmustega toimetulekul ja jutustaja isiksuse kujunemisel. Teiseks naturaalne-lakooniline sündmuskirjeldus arreteerimisest ja ülekuulamisest, mida tasakaalustab mõtete kogumise kirjeldus neist hetkedest, kui ta on kongis. Nende olukordade kirjeldustesse ei mahu mõtisklused ega hinnangud. Tähelepanu on koondunud olukorra ootamatuse ja sellega kohanemise kujutamisele. Kolmandaks, oma elu mõtestamine nõnda, et vangistus sündmusena ei ole keskne tema elus. Samas tuleb rõhutada, et vangistusperioodi eristab teistest perioodidest teatav teistsugusus: teekonnad "loomavagunites"; see on eluperiood, mida iseloomustab "kiskjalik võitlus oma elu eest" ja mis ei taandunud temast jälgi jätmata. Vangistuse kirjeldamise seisukohast on tema lugu seestpoolne vaade, mis ei võimalda esile kerkida välisvaatleja ootusel leida tema jutustustest massikultuurist tuntud trauma keelt, milles pühendutakse trauma näitamisele märkimisväärselt enam kui omaeluloolises tekstis. Neljanda traumaaspektina võib välja tuua üht lauset tema küllalt pikast loost. See puudutab retoorilist väidet, et "selle koletu teo väljamõtlejaid, organiseerijaid ja täideviijaid nagu poleks olnudki”. See väide puudutab 1990. aastate ametlik-avalikke hoiakuid ja inimesi ühiskonnas nii, nagu tema seda näeb. Sellest võib järeldada, et tema seisukohast ei ole stalinlike repressioonide teema avalikkuses nõnda jutuks tulnud, et ta enda ja ühiskonna (riigi) vahelise suhte korda saaks. Vajaka jääb sellest, kuidas aktsepteerida Eesti ühiskonnas neid ja nende lugusid, kes nõukogude repressioonidele mingil viisil kaasa aitasid. ${ }^{20}$ Võimalik ka, et tegemist ei ole niivõrd tema ja ühiskonna, kuivõrd tema ja kaasinimeste vahelise teemaga. Vaikimisi võiks traumat näha ka lähisuhete kirjelduses: poliitilised arengud lämmatavad tema neiueaotsingu ja ta ei saavuta sellist pereelu, nagu ta oma vanematega seoses on kirjeldanud. 
Teine lugu. Loo minategelane on sündinud Riias 1912. aastal ukrainlasest isa ja eestlannast ema perre. Nii jääb tema eluaega kolm sõda: Esimene maailmasõda, Vabadussõda ja Teine maailmasõda. Erinevalt eeltutvustatud jutustajast ei ole teda vangistatud ega küüditatud - kõike seda koges ta kas pereliikmete või naabrite käekäigu kaudu. Tema loo traumaatiliste kogemustega seotud tahud võiksid olla individuaalset ja perekondlikku laadi: isa kaotus, ema eemaldumine, töötus, lapse ränk haigestumine, naise argiväsimus. Kuid need põimuvad suuremas osas ajaloolis-poliitiliste olukordadega. Isa kaotus ja ema eemaldumine perest johtub vahetult Esimesest maailmasõjast: isa hukkumise järel ei suutnud ema uue olukorraga toime tulla ja jutustaja kasvab üles vanaema juures. Töötusega seotud meeleheite ehk "elutüdimuse" kogemine asetub 1920. aastate lõpu ja 1930. aastate alguse majanduskriisi. Paariaastase lapse haigestumise tõi kaasa lapse sattumine lahinguväljale Teise maailmasõja ajal. Naise väsimust raamib märkimisväärselt nõukogude perioodi algusaastate kitsikus.

Seda lugu iseloomustab fookuse püsimine argielul ja isiklikel sündmustel. Varast perioodi jutustaja elus saadavad ühelt poolt kehv elujärg ning sõjast ja linnakeskkonnast inspireeritud laste mängud ("isegi ühe naelaga võisin mängida, mis siis veel rääkida, kui neid terve pihutäis oli”). Teisalt tuleb esile lapseea rõõm ja vanaema oskus kehvades tingimustes kodust kaitstust luua. Intervjuus tuleb vanaema hool ja oskus kitsastes oludes rõõmu luua eriti esile. Intervjuus kõlab selle perioodi kirjelduse kokkuvõte nii: kõht oli tühi, muidu kõik oli hästi. Kuid sellega kaasneb ka jutustaja moraal: kui inimesel on asju vähe, oskab ta neist eriti rõõmu tunda. Sellist jutustamisviisi kannab nii kirjalik elulugu kui eriti ka suuline intervjuu: kõik raskused ja kitsikused seostuvad elutarkusega, et igas olukorras võib hakkama saada nõnda, et tunnetatakse oma elu väärtust.

Alates kaheksandast eluaastast hakkas jutustaja linnalähedastes taludes suviti karjaseks, kus tööharjumusele lisaks kogunes aasta-aastalt teadmisi nii talu argielust kui pühadest. Eluloos võib kohata ka vihjeid sealse kogukonna tõekspidamistele (“tüdrukul peab kogu aeg mingi töö käsil olema”). Linnas puutub ta kokku nii aktiivse usuelu kui laulmisega. Ka tema jutustusest võib aimata empaatia kujunemist lapseeas. Tema arutles lapsena kirikus käies Kristuse kuju vaadates, "miks Jumal nii kurva näoga on, kas teda vaevab mõni mure" (lk 21). Viieteistaastaselt saab ta Singeri õmblusmasina ja käib masintikandi kursustel. See on oluline tähis, sest sellest ajast tegeleb ta õmblemise ja tikkimisega nii oma pere tarbeks kui ka müügiks. Neiuna töötab ta põhiliselt linnas - kohvikus, juuksuriäris ja vabrikus. Traumaatilisena kogetud sündmuseks kirjeldatud eluperioodist (1930. aastate alguses) on töötus: 
Kerget elu pidi olema väga raske elada. Mina ei ole pidanud tööd raskeks, vaid elu loomulikuks osaks. [Aga ühel päeval] juhtus selline lugu, et mul polnudki tööd. (Lk 22)

Ta lootis saada tööd kammivabrikus, ja selleks tuli minna igal hommikul vabriku väravasse, kus tööle soovijaid oli "saja ringis", valituks osutusid aga üksikud. Ka tema osutus korra selleks, kelle käest küsiti, mida ta oskab, ent tööle ta seekord siiski ei saanud.

Olin meeleheitel ja elust tüdinud. Must masendus tuli peale. Kõht oli tühi ja tundsin ennast mitte kellelegi vajalikuna. Nü̈̈d on välja mõeldud sõna "masendus". Tol ajal valdas mind elutüdimus. Kujutage ette, olin siis alles 20-aastane. (Lk 22)

Nii tütre kirja pandud eluloos kui ka meie kohtumisel esitas ta väga selgepiiriliselt selle seiga üksikasjad: mida tähendas talle töötus, kuidas ta kauples end tööle, kuidas see ei õnnestunud ja kuidas ta otsustas oma elu lõpetada, ent enne otsustas ta veel kord vabriku väravas õnne proovida - ja just sel hommikul osutuski tema tööle valituks. Võib mõista, kui keeruline oli see olukord tema jaoks sündmuste toimumise ajal. Rääkimise ajal on aga traumaatilisuse asemel esil õpetlik sõnum - ka kõige raskemast situatsioonist võib ometi välja tulla.

Kuna järgnevad aastad tema elus ja Eesti ühiskonnas liikusid tõusuteed, siis eluloo järgmistes episoodides on juttu elujärje paranemisest, millega kaasnes ka ümbruskonna muutmine kaunimaks. Kuna tema elas linnas, siis on juttu kinost, filmidest ja popkultuurist, nagu üldse uuest elustiilist, mis hõlmas nii päikesevõtmist kui reisimist. Mõistagi see kõik ei olnud võimalik kõigile, sest tööliste palk kõiki hüvesid ei võimaldanud. Sel perioodil tuleb tema ellu noormees ja nad loovad pere. "Oma vähenõudlikul viisil olin eluga rahul.[---] Oma kodu, söök laual ja riided seljas" (lk 28). See on seisund, milles tabas tema peret Teine maailmasõda, mil "tuli mehe arreteerimine ja vangilaager. Tulid kohutavalt rasked ajad" (lk 28). Pärast sõda, kui oli raske kõigil, tasapisi siiski kõik rahunes. Ent siis toimus pööre pereelus. Ta ei kirjelda pikemalt seda kurbust ega tühjustunnet, mis viis lahutuseni. Sellest ei taha ta jutustada põhjendusel, et mitte kõike veel kord läbi elada, liiati avada enda haavatavust võõrale. Siiski ütleb ta - armid jäid kogu eluks. Vaikimine eluloos viitab traumaatilisele kogemusele, ent ühtlasi ilmneb, et see on ka kaitsereaktsioon (jutustades tuleks need olukorrad ja tunded uuesti läbi elada), ja et need teemad ei ole avalikkusega jagatavad. Ilmneb, kuidas individuaalsel tasandil kogetu ei sobi vahetult avalike arutelude teemaks - viimane eeldaks mingit ülekannet (nt kunstilist üldistust vms konkreetsest isikust distantseerivat esitusviisi). 
Samalaadset jutustamisstrateegiat on käsitlenud Katalin Henriksson Rootsis elavate ungarlaste eluloojutustusi analüüsides. Ta märgib, et traumaatilisest kogemusest tingitud vapustus ei võimalda seda sõnas kirjeldada ilma jutustajat ennast puudutamata. See on üks põhjus, miks traumaatilisest kogemusest on keeruline kõnelda. Samas aga on traumaatiline kogemus midagi sellist, mis vajab väljaelamist ja see viib jutustaja reaalsuse ja fiktsionaalsuse piirile (Henriksson 2015: 41-42). Fiktsionaalsust võib kõnesolevas loos näha filmide ja kuulujuttude põimimisel loosse, kui ta kirjeldab Teist maailmasõda. Selle sõjaga seoses meenutab ta ka oma varasemat sõjakogemust ning seostab need ajalooliste filmidega. Vahetust kogemusest on tal meenutada aga nii sõja alguse kui lõpu rinde üleminekuga seotud äärmiselt ohtlikud olukorrad. Ta lähedased olid jäänud rindeületamise alale ja “[r]äägiti, et kõik on tapetud ja lapsed teiba otsa aetud. Sõjaväe saagiks olid langenud koduloomad ja -linnud, isegi koertele ei antud armu" (lk 31). Üks lastest haigestus nii, et arst kahtles, kas ta suudab last päästa. Nii selles lahingujälgede kui ka lapse ravimise kirjelduses mängib olulist rolli keegi, kes oskab ja suudab teha head: "Kõik head inimesed pole aga ka rasketel aegadel kadunud". Kuid heale inimesele lisandub ka õnn, ning ta lisab: "Jumal oli olemas!" (lk 32). ${ }^{21}$

Mehe arreteerimise ja ligi kaks aastat kestnud vangilaagri kogemus pärineb temal Saksa okupatsiooni ajast. Ta ei räägi sellest pikalt, ent aimata võib eestlaste omavahelist suhtlemist võõrvõimu tingimustes: on pealekaebajad, vange halvasti kohtlevad vangivalvurid, aga on ka töökaaslased, kes annavad allkirju mehe päästmiseks. Nõukogude võimu taaskehtestamise perioodist tulevad esile taas samad kogemused: on inimesi, kes vahetavad oma tõekspidamisi ja minetavad südametunnistuse, kes reedavad ja kaebavad. Ta väidab, et ka Siberist tagasi tulnud inimesi kiusati jätkuvalt, "ometi ei saadud nende inimeste hinge murda" (lk 38). Taas tuleb esile tõdemus, et võõrvõimust ja sõjast tingitud kriitilised perioodid muudavad inimesi (või pigem - toovad inimestes midagi sellist esile, mida rahuajal sellisena ei märka) - nii nagu linn oli varemeis, olid "umbe kasvanud ka inimhinged". Enda kohta ütleb ta: "Elasin ränkrasket elu. Halvaga ei tohi harjuda. Tuleb loota ja tegutseda" (lk 34). See on arutelu, mis kätkeb endas inimeste vaheliste suhete ja neid esile kutsuvate ajaloolispoliitiliste olukordade vastastikmõju seoseid. Kui esmalt kirjeldatud eluloos oli jutustaja ja ühiskonna suhe esitatud mõneti vastandlikuna - see on seisukoht, mis lähtus tema vangistuse ja pere küüditamise kogemusest -, siis siinse loo jutustaja osutab pigem sellele, et ühel ja samal ajal toimivad ühiskonna eri tasanditel mitmed tõekspidamised. See on olukord, mis on väljakutseks kõigile ühiskonna liikmetele, sest inimene peab suutma kohaneda. Siinne jutustaja jõuab kokkuvõtteni, et "ajaloos võivad tõed muutuda lõpmatuseni, inimeses väljakujunenud tõed ja tunded jäävad igaveseks" (lk 36). See haakub esmalt 
kirjeldatud eluloo jutustaja tõdemusega: ka tema osutas pere ja seal omandatud väärtuste tähtsusele enda isiksuseks kujunemise loos, ja ka tema sõlmis selle protsessi lahti ühiskonnas parasjagu esile tulevatest hoiakutest.

Omaette lõik eluloos on pühendatud jutustaja suhetele oma emaga. Neid võib käsitleda trauma vaatenurgast. Kuigi ta oma ema tundis, kasvatas teda siiski vanaema. Emaga läbikäimine ei olnud selline, mida tütar oodanuks. Jutustaja vaate järgi ei suutnud ema oma eluga toime tulla. Ta ei tea, mis konkreetselt oli selle põhjus - noore naise saatus pärast mehe surma ei olnud ilmselt emale jõukohane, arutleb ta. Kuigi jutustaja väidab, et ta on emale andestanud, on selles episoodis ilmne ka tunnete ja kahtluste mitmesus. Taas tuleb esile sordiini all jutustamise viis - ta ei kõnele ema tegemistest, iseloomust, seisukohtadest vm midagi täpsemalt. Ta annab lihtsalt endapoolse kokkuvõtte enda ja ema suhete loomusest ja selle eeldatavast põhjusest. On ilmne, et siin ei ole sellise varjatud esituse põhjuseks mitte niivõrd enda valu või pettumus (ta on emale andestanud), kuivõrd see, et tegemist on teise inimesega. Ta ei paku lugejale arutamiseks teise inimese elu. Igal inimesel on õigus oma lugu ise rääkida.

Selle jutustaja loos puudub äärmuslik kogemus tsivilisatsioonipiiri ületamisest, mida tundsid vangistatud inimesed. Temas koonduvad kõikide aegade traumaatiliste kogemuste võimalikkused pere- ja argiellu. Ka tema loos on traumaatiliste kogemustega toimetulekul olulisel kohal kokkuvõte: olgu elu kui keeruline tahes, alati tuleb anda endale võimalus oma elu väärtustada. Tugevad inimesed seda suudavad (nagu tema vanaema näiteks). Erinevalt eelkirjeldatud jutustajast ei sea tema kahtluse alla tänapäeva ühiskonna lahknemist nõukogude võimu esindajateks või kaasaaitajateks ja nendeks, kes selle tõttu kannatasid. Tema kogemus ulatub üle nõukogude võimu represseerimiste ja samas ta teab, et kogukonnas on igasuguseid inimesi. Hoiatusena mainib ta: kurjusega ei tohi harjuda. Tema loo traumaatilisi kogemusi vahendavad episoodid puudutavad teda ennast: tema suhteid ema ja abikaasaga. Isiklike traumakogemuste mainimine ei leia laiendamist kahel põhjusel. Esmalt ei taha ta neid tundeid uuesti läbi elada, mis jutustamisel vältimatult juhtuks. Teiseks - ta ei ava end võõrale, nagu ta ei ürita ka oma ema lugu esitleda rohkem, kui on ta enda loo mõistmiseks vajalik. Nii tema enda kui ka tema ema (aga ka teiste pereliikmete) privileeg on jääda võõra pilgu eest varjatuks, kui tegemist on selliste kogemustega, mis tooksid kaasa asjaosalisele valu ja võõraste hinnanguid. 


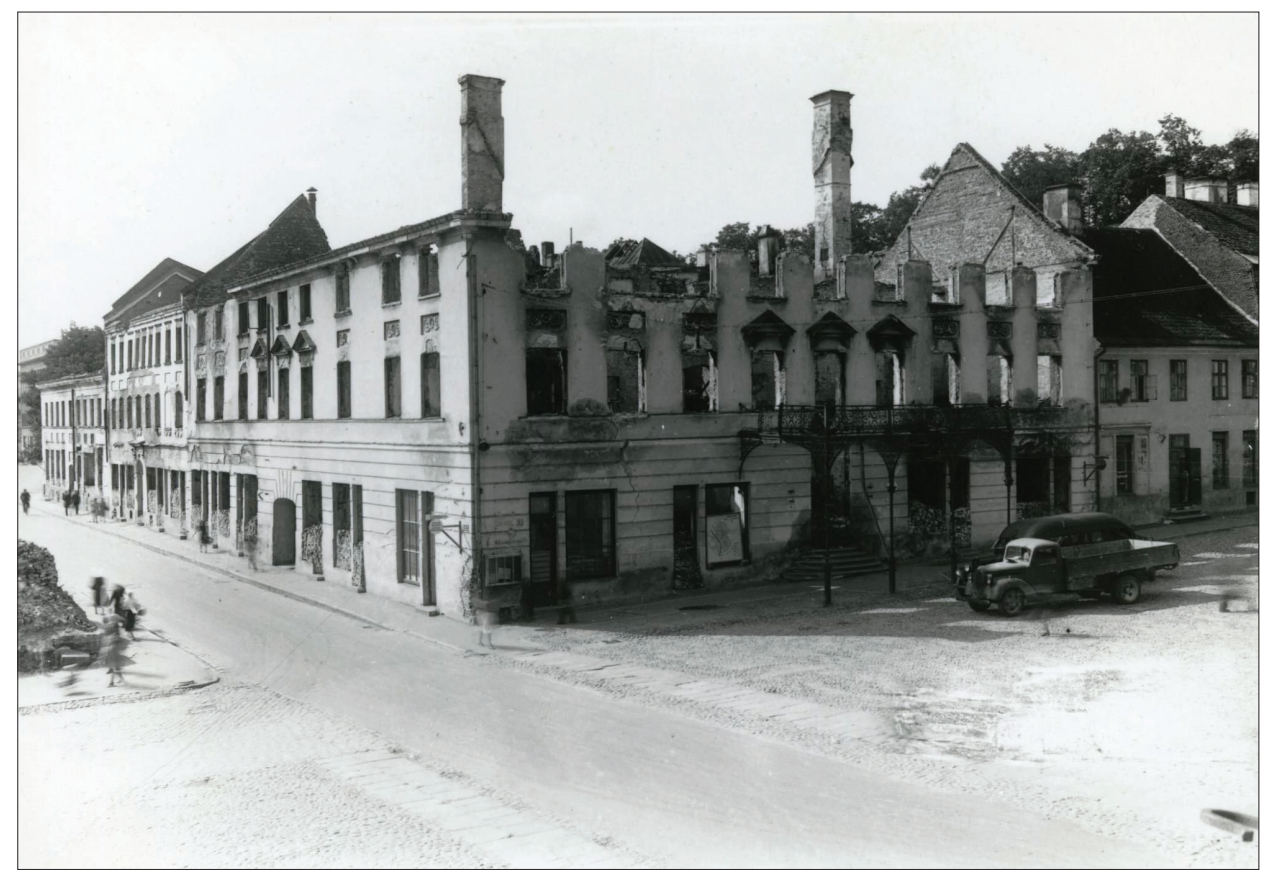

Foto 1. Nii nagu sõda laastas linnu, räsis ta ka inimhingi.

Vaade Tartu Raekoja platsilt Kü̈̈ni tänava suunas. Foto Kaljo Pärna erakogust.

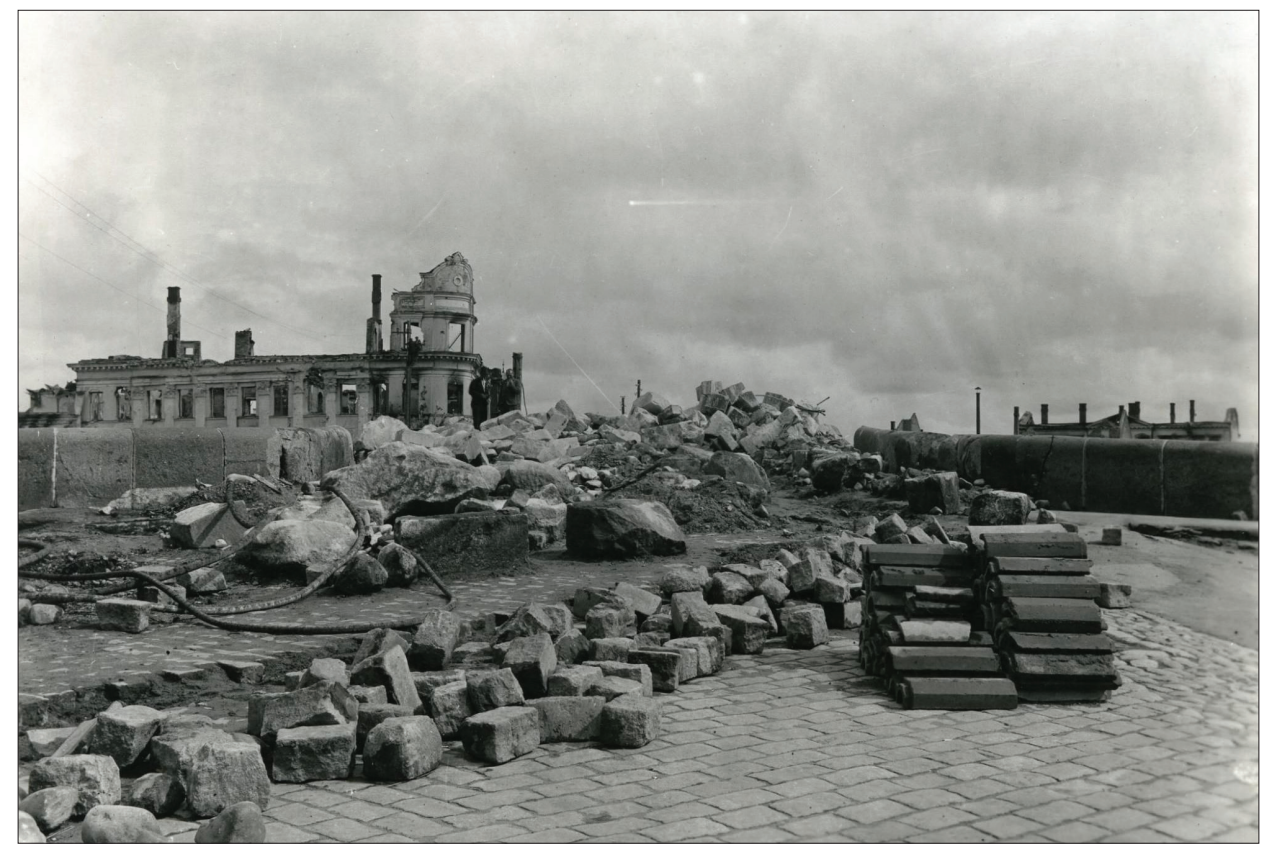

Foto 2. Vaade Tartu Raekoja platsilt Kivisilla varemetele.

Pildistanud Eduard Selleke, august 1941. Foto Kaljo Pärna erakogust. 


\section{Kokkuvõte}

Folkloristlikust vaatepunktist esindavad Eesti elulugude kogu käsikirjalised tekstid jutustaja loo ühte varianti. See tuleb eriti esile, kui võrrelda sama jutustaja loo erinevaid esitusi. Siinses artiklis oli võimalik võrrelda arhiivi saadetud kirjalikke esitusi ja välitöömaterjale. Üks jutustajatest on saatnud oma kaastöid nii elulugude kui ka Eesti Rahva Muuseumi korraldatud kogumisvõistlustele. Viimati mainitud kaastöödes on uurijate koostatud küsimustik märkimisväärselt nähtavam kui eluloos. Esituste kõrvutusest koorus aga siiski välja tuumlugude stabiilsus. Jutustaja valdab võrdselt nii teabe- kui ka arutluskeskset esitust. Millist stiili valida, sõltub ühelt poolt teemast (vangilaagriga seonduv on pigem teabekeskne, vanemate kodust pärit elukestvate tõekspidamiste esitus pigem arutluskeskne), osalt küsimustiku eripärast (vangilaagriteemat puudutava küsimustiku autor Edgar Saar esindab pigem teabekeskset stiili, samas Heiki Pärdi suunab küsimustikus "Elu nõukogude ajal" esile tooma pigem suhteid, seoseid, vaatepunkte). Ka teise siin analüüsitud jutustaja lugude võrdlus (ühelt poolt jutustaja tütre kirja pandud elulugu, teisalt suuline vestlus jutustaja endaga) osutab tuumlugude stabiilsusele, hoolimata vestlus- või kirjutamisraamist, mis neid lugusid tervikuks seob. Tuumlugude püsivus ühelt poolt ja jutustamisraamide muutlikkus teiselt poolt toob esile jutustamise traditsiooni järjepidevuse. Loo kujunemine pidevas tasakaalu otsimises stabiilsuse ja kohanemise vahel ei ilmneks ühe kirjalikuna fikseeritud teksti kaudu, kuna see mõjub lõpetatuna, ühekordse ilminguna.

Viljakaks osutuks tuumlugude ja aruteluosade keeleanalüüs: näiteks kas või millal loobutakse "Siberisse viimisest" "represseerimise" kasuks; millal ja mis tingimustel ilmub lugudesse teave vangistuste ja asumisele saatmise põhjustest (sh nt mil määral loetakse ja tõlgendatakse omaaegseid ülekuulamisprotokolle). Siin analüüsitud lugude keelekasutuses võis näha teatavaid eelistusi: inimesed viiakse Siberisse, neid kü̈̈ditatakse, Siberist tullakse tagasi, vangistatud jutustaja nimetab kohtuotsuse määramist oma eluloos irooniliselt premeerimiseks. Need on mitte ainult kultuurisidusad (eesti kultuuriruumis on Siberil vangistustega seotud tähendus, mida kasutatakse ka metafoorselt ${ }^{22}$ ), vaid ka ajaloolisest situatsioonist tingitud fraasid (nõukogude ajal oli mõistlik rääkida poliitilistest vangistustest kaude, kujundkeele abil, mida omakorda soosis rääkijate endi ja ametlike käsitluste vastuolulisus). Sõnade ja fraaside muutus viitab jutustamisega seotud üldraami muutumisele (näiteks kirjeldavate sündmuste asendi muutus avalikes käsitlustes, omaaegsete dokumentide keelekasutuse imbumine jutustusse jms).

Analüüsitud kaks elulugu on jutustatud 1990. aastate lõpul, 2000. aastatel. Need ei esinda rahvapärast trauma keelt üldiselt, küll aga osutavad 
mõnedele tunnustele, mida võiks sajandivahetuskümnendite rahvapärasest trauma keelest otsida. Üheks selliseks on talitsetud esitus. Jutustaja mainib, ent ei ava isikliku eluga seotud läbielamisi. Seda põhjendatakse kaheti. Esmalt: jutustamine ei säästa jutustajat omaaegsete tunnete uuesti läbielamisest. Seda ei taheta kogeda. Teisalt lähtub valik mitte rääkida kultuurinormidest: võõrastele ei avata kõiki isikusse puutuvaid seiku. See kehtib nii enda kui ka teisest inimesest jutustamise kohta. Sellist esitusviisi toetab eluloožanri jutustaja-kesksus, kus valusatest asjadest rääkimine ei võimalda piisavat distantsi kogetu ja sellest kõnelemise vahel. Kui tegemist on stressiolukorraga, mida põhjustab pinge üldise olukorra ja individuaalse läbielamise vahel, võib trauma keelt otsida folkloorsete motiivide kasutuses (nt unenäod, kuuldused, ennustused). Ühes siin analüüsitud tekstis võis seda leida sõjakirjelduses: ühelt poolt nn räägiti-et-hirmulood ja teisalt need läbielamised, mida kirjeldatav lahing tõepoolest endaga kaasa tõi. Kuna hirmule viitavad lood aktualiseeruvad olukordades, mida kogukond tajub stressi tekitavatena, võiks rahvaluule motiivide kasutusanalüüs pakkuda traumauuringuteks uusi võimalusi. Selle vaateviisi muudab eriti põnevaks asjaolu, et ühelt poolt on need motiivid püsivad, teisalt aga motiivide kasutusseos (hirmu metafoorne kujutamine, huumor, ajastutunnetuse kirjeldus vms) teiseneb vastavalt taustsüsteemi muutumisele. Vangistus- ja küüditamislugude trauma keelele on tunnuslik loomakujundite kasutamine (eriti kodust asumisele või vangistusse viiva teekonna läbimine nn loomavagunites), samuti kohtlemine esemetena (meid sorteeriti).

Vangistus- ja ülekuulamissituatsioonist räägitakse juhul, kui eeldatakse lugeja empaatiat ja oskust kõnesolevat olukorda ajalooliselt kontekstualiseerida. Enda avamist võõrale selles olukorras toetab jutustaja eeldus, et üldiselt on seisukoht nõukogudeaegsetest vangistustest kui ebaõiglasest kohtlemisest omaks võetud. Sellegipoolest kasutatakse napisõnalist kirjeldust, vältides laiendusi, edasiarendusi vms. Tõenäoliselt on selline valik põhjendatav asjaoluga, et nii säästab jutustaja end tolleaegsest valukogemusest ja alandatuse tundest. Kuid samuti on võimalik, et toonane olukord ise ei võimaldanud meeleolutseda. See - meeldejätmise hetk - kajastub omal moel ka meenutustes.

Elulugude trauma keel viitab ühelt poolt jutustaja elutõe kujunemisele, teisalt aga jutustaja-mina säästvale esitusele. Kuna tegemist on jutustaja enda elus toimunud sündmustega, saab ta olnut kirjeldada teatud distantsiga: tal ei ole võimalik uuesti läbi elada ja kirjeldada kõiki detaile, mida saab kujutada väljastpoolt vaatleja talle omase distantsi tõttu. Kuna tegemist on eluloojutustustega, siis on ootuspärane, et traumaatilisele kogemusele leitakse tähendus kogu elu silmas pidades. Ühtlasi ilmnes, mil viisil seostuvad avaliku arutelu teemad ja kujutamisviisid omaeluloolises tekstis. Neid seoseid võib iseloomustada dialoogina, milles sisaldub nii enda elu üldiste hoiakutega võrdlevaid sei- 
sukohavõtte (näiteks suhtumine vaesusesse ja sellega toimetulek ühiskonnas) kui ka paralleele (näiteks andeks palumine lähisuhetes võrrelduna riigipea poliitilise väljaütlemisega).

Vaadeldud elulugudele on iseloomulik, et traumaatilised kogemused esitatakse ühendatuna elu õppetunni ja moraalse kokkuvõttega. Nii võib traumat neis elulugudes mõista kui üht mõjutegurit elukogemuse kujunemisel. Ent kui ühelt poolt on trauma elukogemuse eelduseks, siis teisalt on traumaatiline kogemus alati läbi põimitud mitmete arutluste ja tunnetega, mille kaudu traumaatiline kogemus asetatakse oma kohale jutustaja kui isiksuse kujunemisloos. Samas tuli ilmsiks, et eluloost võib leida teemasid, mis ei avane samas võtmes, kuid milles uurija võiks näha traumaatilist kogemust. Näiteks antud juhul sõja- ja sõjajärgsesse aega paigutuva armastusloo katkemine, mis ei võimaldanud jutustajal kogeda sellist pereelu, mida ta oma lapsepõlvekodu ja vanematega seoses kirjeldab. Samas ei pruugi seda käsitleda üksikisiku traumana (kui jutustaja seda nii ei näita). Pigem suunab see juurdlema poliitiliselt keeruliste olude osast pere kujunemise ja toimimise vaatepunktist. Siit edasi järgneb aga küsimus üksikisiku traumaatilise kogemuse mõjust lähedastele või ka üldisemalt kogukonnale. Järeldub, et trauma on äärmiselt dünaamiline nähtus, mis võtab oma arengus uusi ja uusi suundi ja põimib üksikisiku ning kogukondlikke suhteid.

Kuid mida pakub eluloo traumaatiliste kogemuste vaatlus ühitatuna traumateooriaga? Ilmneb, et neis esitletav trauma ei kattu. Samas aga võimaldab traumauuringutega seostatud elulugude käsitlemine arutleda selle üle, kuidas suhestada isiklikud ja konkreetsed kogemused üldiste hoiakutega, mida pakub traumateooriast lähtuv käsitlus. Kõige üldisemalt võiks öelda, et seda seost võib leida üldistes arusaamades vägivallast, ülekohtust, traagilisi tagajärgi esilekutsuvatest sündmustest. "Trauma” seotus kogemuse ja selle esitusega on aga kummaski eripärane, alustades sellest, kelles nähakse oma sõnumi kuulajaskonda, lõpetades individuaalse distantsi olemasolu või puudumisega kujutava sündmuse ja kogemuse suhtes.

\section{Kommentaarid}

1 Artikkel on seotud Soome Akadeemia projektiga Traumatized Borders: Reviving Subversive Narratives of B /Order, and Other ja Eesti Haridus- ja Teadusministeeriumi rahastatava projektiga IUT 2-42 "Traditsioon, loovus ja ühiskond: vähemused ja alternatiivsed diskursused".

2 Artikkel seostub uurimisprojektiga "Traumaatilised piirid...", mille teemaks on piiride ja piiriületusega seotud traumaatilised kogemused Soomes ja Eestis. "Traumaatiliste piiride" projekti (http://www.uef.fi/en/web/traumatized-borders) tegevustuum seisneb 
küsimuses, kuidas mõjutab ajalugu tänapäevaseid mentaalseid hoiakuid, sh millised mõjutegurid tingivad traumaatiliste kogemuste aktualiseerumist ja esitusi (nt unustamist, mahavaikimist, avalikkuse eest peitmist või vastupidi - esiletoomist). Uurimisfookuses on traumakogemuse väljendusviisid (elu)loo jutustamisel. Artikli seotus teise, üldisema projektiga "Traditsioon: loovus ja ühiskond" väljendub käsitluse lähtepunktis: uurimus on üles ehitatud jutustaja ja jutustamise keskselt, mitte traumateooriast lähtuvalt.

3 Eesti elulugude kogu sai alguse 1989. aastal ja täieneb jätkuvalt, sisaldades praegu umbes 3000 käsikirjalist omaeluloolist jutustust. Nende lugude baasil on avaldatud mitmeid kogumikke, näiteks "Naised kõnelevad" (1997), "Kured läinud, kurjad ilmad" (1997), "Me tulime tagasi" (1999), "Võimas ja sünge Patarei" (2007), "Sõja ajal kasvanud poisid" (2011), "Mina, õpetaja" (2015), tuntuim kogu on Rutt Hinrikuse koostatud "Eesti rahva elulood" I-III (2000-2003). Käsikirjalised lood on saadetud kirjandusmuuseumi peamiselt temaatilistele kogumisvõistlustele. (Vt täpsemalt Hinrikus 2016: 258-261.) Uurimise seisukohast on oluline arvestada, et käsikirjalised arhiivitekstid ja nende põhjal koostatud ning avaldamiseks toimetatud versioonid võivad üksteisest märkimisväärselt erineda.

4 Näiteks kujutab 1912. aastal sündinud naine kohtumist noormehega, kellest saab tema abikaasa ja laste isa järgmiselt: "See oli minu saatus. Eksikombel osutus "saatus" elumeheks. Erutav vaatemäng võis alata.” (EKLA f 350, 2414: 27.) Selles esitusviisis märgib "saatus" nii elu muutvat sündmust (kohtumine mehega, kellega jutustaja loob pere), elumuutuse kujundajat (meest) kui ka viidet tulevikule (kohe antakse teada, et järgnev elu abielunaisena kujuneb keeruliseks).

5 Etümoloogia sõnaraamatust nähtub, et sõna "saatus" on seotud sõnaga "saama". Murdesõnastikes seda sõna (mõistet) ei kohta.

${ }^{6}$ Vt nt Eesti Kirjandusmuuseumi folkloristika osakonnas loodud e-andmebaasi "Eesti mõistatused" aadressil http://www.folklore.ee/moistatused/.

7 Vt nt Eesti Kirjandusmuuseumi Eesti Rahvaluule Arhiivi kogu (või ka selle põhjal rahvaluule arhiivis koostatud "Eesti regilaulude andmebaasi" http://www.folklore. ee/regilaul/andmebaas/: H II 40,1001 (92); H III 8, 191/4; H III 29, 23 (5); E 32541/2 (1/108); E 81520/2 (28); E StK 21, 55/6 (25), ERA II 17, 226/7 (154).

8 Vt Eesti Kirjandusmuuseumi vanasõnade e- andmebaasi "Eesti vanasõnad" aadressilt http://www.folklore.ee/rl/date/robotid/leht1.html (otsisõna "saatus").

9 Vt kõnekäändude ja fraseologismide e-andmebaasi “Justkui” http://www.folklore.ee/ justkui/.

${ }^{10}$ Näiteks kirjutab 1923. aastal sündinud naine oma pere küüditamisest märtsis 1949 ennetavalt "saatust" mainides: "Taluvõlg kustus nõukogude korra alguses ja esialgu see rõõmustaski. Hiljem, peale küüditamist, selgus võlakustutamise mõte, hakati mõtlema sovhooside loomisele ja "kulakuks" tegemistele ja ka meie peret ootas kurb saatus ...” (EKLA f 350, 444: 56).

11 Teemajutustuse mõiste folkloristikas lähtub teemakirjutuse ja see omakorda teemaintervjuu mõistest. Mõiste on kasutusel tõsielule tuginevate ja arhiivi saadetavate kirjalike kaastööde nimetamisel (Pöysä 2009: 40-41; Jaago 2014: 9-11). Ka käesolevalt analüüsitavad elulood on kirjalikud kaastööd arhiivi korraldatud kogumisvõistlusele, ent elulugude kogumisvõistluse teemad on enamasti piiritletud nõnda, et need võimaldaksid rääkida vabalt kõikidel inimese elukäiku puututavatel teemadel (vt eesti elulugude kogumisvõistluse teemasid 1989-2005 Kõresaar 2005: 24). 
${ }^{12}$ Samaaegselt traumateooria kujunemisega, kus ajaloosündmuste käsitlemisel pöörduti kangelasteemalt (sh monumendid, tähtpäevad) ohvriteema juurde, toimus ka kangelase mõiste ümbermõtestamine (vt nt Kemppainen \& Peltonen 2010).

${ }^{13}$ Näiteks arutleb siin artiklis analüüsitud eluloo autor: "Olen kogenud ka seda, et mulle ülekohut teinud inimesele ei luba "hääl" ["hääl" on seotud "usuga üleloomulikesse jõududesse" - T. J.] kätte maksta võimaluse korral, vaid kõik jätta saatuse hooleks. Ülekohtule tasub aeg ise pikapeale kätte ja kui mina olen oma pika elu jooksul kellelegi ülekohtune olnud, siis on saatus mulle selle topelt kätte tasunud ...” (EKLA f 350: 444, lk 101).

${ }^{14}$ Mälu vormi või ka [trauma] keele mõistet selgitab Eneken Laanes Ann Rigney mälu-uuringutest lähtuvate seisukohtade kaudu: "minevikust ei saa rääkida ükskõik kuidas", sest jutustamisel saab kasutada vaid neid viise ja võtteid (sh sõnu), mida kõneleja kultuuris tuntakse (Laanes 2017: 242). Folkloristlikus jutu-uurimises tõusis see teema päevakorrale kognitiivse psühholoogia ja antropoloogia mõjuväljas 1980. aastatel, kui küsimuseks oli mõtlemisviiside ja informatsioonikäsitlemise omavaheline seotus, mis tagas rahvapärimuse stabiilsuse, alalhoidlikkuse (vt nt Kaivola-Bregenhøj 1988: 23 jj; Apo 2003: 218-219).

${ }^{15}$ Rutt Hinrikuse koostatud ja toimetatud kogumikule "Eesti rahva elulood" lisandus 2003. aastal ka kolmas osa, mis on temaatilise (mitte kronoloogilise) ülesehitusega.

16 Tuumlugu on sündmuste esitus, mida kasutatakse tervikloo jutustamiseks (Veidemann 2002: 26). Eluloos järjestatakse tuumlood, pidades silmas elukäiku ja selle mõtestamist, teemajututuste puhul allutatakse tuumlood kesksele sõnumile, mida antud teema puhul oluliseks peetakse

${ }^{17}$ Eneken Laanese (2017: 247-248) käsitlusest tuleb esile avalike tekstide domineeriv roll Eesti elulugude kogus olevate tekstide üle, millesse ma folkloristina suhtun ettevaatusega. Kirjandusteadlaste tekstitundmine võib mõjutada seda, kuidas elulugusid mõistetakse, ent see ei tähenda, et jutustajate tekstitundmine kattub uurija omaga. Folklkorist Anne Heimo näitab 1918. aasta Soome kodusõja uurimuses ajaloosündmuste rahvapärase tõlgendamise komplitseeritust, kus vahetud kogemused põimitakse kodu-uurimuslike, ajaloo-alaste, kirjanduslike jm tekstidega (sõltudes nende autoriteetsusest jutustaja silmis). Ent kõrvale ei saa jätta kaudsemaid tõlgenduse mõjutegureid, nagu vaenlase kujutamisviisid, üldise ja kohaliku tõlgenduse ühitamine, kohalik intertekstuaalsus jms (Heimo 2010: 99 jj).

18 Jutustaja kasutab nimelt seda sõna: “arreteerimine”, et märkida ühe oma eluetapi vangistusperioodi - algust. Sõnastustasandi vaatlus aitab mõista jutustaja positsiooni avalike või ka kogukondlik-privaatsete arutelude ja hoiakute suhtes, samuti nende hoiakute muutumiste suhtes.

${ }^{19}$ Arreteerimise ja vangistuse kirjeldused on nii eluloojutustuses kui Eesti Rahva Muuseumile saadetud loos märkimisväärselt kattuvad. Samas on muuseumile saadetud loos laiendusi ja täiendusi. Need lähtuvad kaastöö aluseks olevast küsitlusest ja puudutavad enamasti laagrikaaslastega ja laagrielu üksikasjadega seotud teemasid (nt ema ja lapse laager, inimestevahelised suhted laagris, kirjavahetus jms), mida ta eluloos vaid põgusalt puudutab.

${ }^{20}$ See teema on mingil viisil ühiskonnas olemas: nt raamatusari "Sortside saladused", Merle Karusoo lavastus "Küüdipoisid (25. märts 1949)" Draamateatris 1999. aastal, mõneti ka Mati Mandeli raamat "Kurjuse aasta Lõuna-Läänemaal 1940-1941", mis ilmus 2007. aastal. Selle teema tõstatab ka Imbi Paju oma filmis , näidates intervjuud Arnold Meriga, kes oli küüditamisega seoses kohtu all. Kuid näib, et Eesti ühiskond 
ei ole valmis selle teemaga süvitsi minema, rahuldudes üksiknäidete (uurimise) ja kunstiliste esitustega.

${ }^{21}$ Hea inimese kujund on märkimisväärselt nähtav ka samast perioodist rääkivates represseeritute lugudes (Jaago 2014: 12-13).

${ }^{22}$ Vt nt Eesti kõnekäändude ja fraseologismide andmebaasist http://www.folklore.ee/ justkui/andmebaas.php: kas Siber või kabel (vargapoiste ütlus); Siberi ülikool (vangilaager); surm siin või Siberis (ütlus enne riskantset ettevõtmist); tule ära paradiisi, mis seal Siberis teed jms.

\section{Allikad}

\section{Eesti Kirjandusmuuseumis}

\section{Kultuurilooline arhiiv}

1905. aasta seltsi kogu - EKLA f 172

Eesti elulugude kogu - EKLA f 350

\section{Eesti Rahvaluule Arhiivi käsikirjalised kogud ja kogude põhjal}

koostatud e-andmebaasid (vaadatud 30. mai 2018)

Eesti mõistatused (http://www.folklore.ee/moistatused/)

Eesti kõnekäändude ja fraseologismide andmebaas (http://www.folklore.ee/justkui/)

Eesti regilaulude andmebaas (http://www.folklore.ee/regilaul/andmebaas/)

Eesti vanasõnad (http://www.folklore.ee/rl/date/robotid/leht1.html)

\section{Eesti Rahva Muuseumis}

\section{Kirjasaatjate vastuste käsikirjakogu}

Elu nõukogude vangimajades ja -laagrites (1998) - KV 890

Elu nõukogude ajal (2001) - KV 983

\section{Soome Kirjanduse Seltsis}

Rahvaluulearhiivi temaatilise kogumisvõistluse "Sõjaaeg" käsikirjalised materjalid (2001) - Sota-aika 


\section{Kirjandus}

Aarelaid-Tart, Aili 2006. Cultural Trauma and Life Stories. Helsingi: Kikimora Publications (http://ethesis.helsinki.fi/julkaisut/val/sospo/vk/aarelaid-tart/cultural.pdf-30. mai 2018).

Aarelaid-Tart, Aili 2016 [2010]. The Theory of Cultural Trauma and Applying to Explain the Estonians' Soviet-Time Mentality (Based on the Biographical Method). Jõesalu, Kirsti \& Kannike, Anu (toim). Cultural patterns and Life Stories. Tallinn: TPU Press, lk 39-76.

Apo, Satu 2003. Rahvapärase mõtteviisi uurimine arhiivi- ja küsitlusmaterjalide abil. Jaago, Tiiu \& Kõresaar, Ene (toim). Pärimus ja tõlgendus. Artikleid folkloristika ja etnoloogia teooria, meetodite ning uurimispraktika alalt. Tartu: Tartu Ülikooli Kirjastus, lk 218-233.

Bal, Mieke 2002. Travelling Concepts in the Humanities: A Rough Guide. Toronto, Buffalo, London: University of Toronto Press.

Debs, Mira 2012. The Suffering of Symbols: Giotto Frescoes and the Cultural Trauma Objects. Cultural Sociology 7 (4), lk 479-494 (doi: 10.1177/1749975512454086).

Heimo, Anne 2010. Kapina Sammatissa. Vuoden 1918 paikalliset tulkinnat osana historian yhteiskunnallisen rakentamisen prosessia. Helsingi: Suomalaisen Kirjallisuuden Seura.

Henriksson, Katalin 2015. Roots and Routes: Life Stories of Exiled Hungarian Women in Sweden. Lund: Lund University (http://portal.research.lu.se/ws/files/5500182/8506468. pdf - 30. mai 2018)

Hinrikus 2016 [2003]. Eesti elulugude kogu ja selle uurimisperspektiive. Hinrikus, Rutt. Kahe vahel. Artikleid kirjandusest ja elulugudest. Tartu: Eesti Kirjandusmuuseumi Teaduskirjastus, lk 252-285.

Hollo, Maarja 2016. Romantiline subjekt, mälu ja trauma Bernard Kangro sõjajärgses loomingus. Dissertationes Litterarum et Contemplationis Comparativae Universitatis Tartuensis 14. Tartu: Tartu Ülikooli Kirjastus (http://dspace.ut.ee/handle/10062/53916 30. mai 2018).

Huima, Leena 2002. Saatuse tahtel. Mäetagused 16, lk 70-94 (doi: 10.7592/MT2001.16. huima).

Jaago, Tiiu 2003. Popular Narrative, Cultural Continuity and Changing Political Regimes. Journal of Indian Folkloristics 5 (1/2), lk 97-108.

Jaago, Tiiu 2006. Individuaalsed valikud ja sotsialiseerumine eluloojutustuste põhjal. Mäetagused 33, lk 83-100 (doi: 10.7952/MT2006.33.jaago).

Jaago, Tiiu 2007. After-effects of War and the Narrative: Depictions of war in Estonian and Finnish life histories in the twenty first century. Suomen Antropologi. Journal of the Finnish Antropological Society 32 (4), lk 45-58.

Jaago, Tiiu 2014. Nõukogude aeg elulugudes - 'katkestus' või 'järjepidevus'. Mäetagused 57, lk 7-28 (doi: 10.7592/MT2014.57.jaago). 
Annikki, Kaivola-Bregenhøj 1988. Kertomus ja kerronta. Helsingi: Suomalaisen Kirjallisuuden Seura.

Kalmre, Eda 2007. Hirm ja võõraviha sõjajärgses Tartus. Pärimuslooline uurimus kannibalistlikest kuulujuttudest. Tartu: EKM Teaduskirjastus.

Kemppainen, Ilona \& Peltonen, Ulla-Maija 2010. Muuttuva sankaruus. Peltonen, UllaMaija \& Kemppainen, Ilona (toim). Kirjoituksia sankaruudesta. Helsingi: Suomalaisen Kirjallisuuden Seura, lk 9-43.

Kirss, Tiina 2002. Põgenemine ja trauma. Looming 12, lk 1870-1880.

Kirss, Tiina 2003. Kolm eesti naist elulugudes. Krikmann, Arvo \& Olesk, Sirje (toim). Võim ja kultuur. Tartu: Eesti Kirjandusmuuseum, Eesti kultuuriloo ja folkloristika keskus, lk 215-245.

Kirss, Tiina 2006. Põgenemisteekonnad ja põgenemislood. Kirss, Tiina (koost). Rändlindude pesad. Eestlaste elulood võorrsil. Tartu: Eesti Kirjandusmuuseum, Toronto Ülikooli Eesti õppetool, lk 611-683.

Kirss, Tiina 2013. Seeing Ghosts: Theorizing Haunting in Literary Texts. Rippl, Gabriele \& Schweighauser, Philipp \& Kirss, Tiina \& Sutrop, Margit \& Steffen, Therese (toim). Haunted Narratives. Life Writing in an Age of Trauma. Toronto: University of Toronto Press, lk 21-44.

Kurvet-Käosaar, Leena 2008. Vaikusse vajunud aeg. Naiste traumaatiline repressioonikogemus Imbi Paju dokumentaalfilmis ja raamatus "Tõrjutud mälestused". Ariadne Lõng. Nais- ja meesuuringute ajakiri 1/2, lk 136-147.

Kurvet-Käosaar, Leena 2014. Crating a Habitable Everyday in Estonian Women's Dieries of the Repressions of the Stalinist Regime. Stroinska, Magda \& Cecchetto, Vikki \& Szumanski, Kate (toim). The Unspeakable: Narratives of Trauma. Frankfurt am Main: Peter Lang Verlag, lk 143-157.

Kõresaar, Ene 2005. Elu ideoloogiad. Kollektiivne mälu ja autobiograafiline minevikutõlgendus eestlaste elulugudes. Eesti Rahva Muuseumi sari 6. Tartu: Eesti Rahva Muuseum.

Laanes, Eneken 2016/2017. 5.3. Mälukultuuri avanemine. Eesti inimarengu aruanne 2016/2017. Eesti rändeajastul (https://inimareng.ee/eesti-kultuurimuutused-avatudmaailmas/malukultuuri-avanemine/ - 31. mai 2018).

Laanes, Eneken 2017. Trauma keelde tõlgitud. Kultuuriülesed mäluvormid eesti laagrija küüditamislugudes. Keel ja Kirjandus 4, lk 241-257 (http://keeljakirjandus.ee/ee/ issues/2017/4/910 - 31. mai 2018).

LaCapra, Dominick 2014 [2001]. Writing History, Writing Trauma. Baltimore: Johns Hopkins University Press.

Leydesdorff jt 1999 = Leydesdorff, Selma \& Dawson, Graham \& Burschardt, Natasha \& Ashplant, T. G. 1999. Introduction: Trauma and life stories. Rogers, Kim Lacy \& Leydesdorff, Selma \& Dawson, Graham (toim). Trauma and Life Stories: International Perspectives. Routledge Studies in Memory and Narrative. London, New York: Routledge, lk 1-26. 
Markowitsch, Hans J. 2002. Autobiographisches Gedächtnis aus neurowissenschaftlicher Sicht. BIOS: Zeitschrift für Biographieforschung, Oral History und Lebensverlaufsanalysen 15 (2), lk 187-201.

Meek, Allen 2015. Cultural Trauma: Biopolitics and the Limits of Responsibility. Borderlands: e-journal 14 (2), lk 1-19 (http://www.borderlands.net.au/issues/vol14no2. html - 31. mai 2018).

Pöysä, Jyrki 2009. Kogumisvõistlused pärimusliku ajaloo uurimises. Mäetagused 43, lk 39-60 (doi: 10.7592/MT2009.43.poysa).

Rothe, Anna 2011. Popular Trauma Culture. Selling the Pain of Others in the Mass Media. New Brunswick, New Jersey, London: Rutgers University Press.

Tael, Tiina (koost) 2006. Mälu paberil. Eesti Rahva Muuseumi korrespondentide võrgu 75. aastapäevaks. Tartu: Eesti Rahva Muuseum.

Talebreza-May, Jon 2015. Cultural Trauma in the Lives of Men in Northern New Mexico. Journal of Men's Studies 23 (2), lk 119-132 (doi: 10.1177/1060826515582521).

Thomas, Jeannie B. 2007. The Usefulness of Ghost Stories. Goldstein, Dianne E. \& Grider, Silvia Ann \& Thomas, Jeannie Banks. Haunting Experiences: Ghosts in Contemporary Folklore. Logan, Utah: Utah State University Press, lk 25-49 (https://digitalcommons. usu.edu/cgi/viewcontent.cgi?referer=https://www.google.ee\&httpsredir=1\&article=1017 \&context=usupress_pubs - 31. mai 2018).

Tulving, Endel 1994. Mälu. Tallinn: Kupar.

Veidemann, Rein 2002. Aja semiootika. Veidemann, Rein (koost \& toim). Aeg ja kirjandus. Artikleid aja kategooria käsitusest, kasutamisest ja toimimisest tekstides. Studia Litteraria Estonicae 4. Tartu: Eesti kirjanduse ning teatriteaduse ja kirjanduse teooria õppetool, lk 9-36.

Welzer, Harald 2000. Das Interview als Artefakt. Zur Kritik der Zeitzeugenforschung. BIOS: Zeitschrift für Biographieforschung, Oral History und Lebensverlaufsanalysen 13 (1), lk 51-63.

\section{Summary}

\section{Trauma and life stories}

\section{Tiiu Jaago}

Assistant Professor, Department of Estonian and Comparative Folklore Institute of Cultural Research, University of Tartu tiiu.jaago@ut.ee

Keywords: folklore research, life story, trauma theory, traumatic experience

The article deals with the manifestation of traumatic experiences in life stories narrated at the end of the 20th and beginning of the 21st century. The manuscripts of these life stories are stored in the Estonian Cultural History Archives. The authors of the stories 
are guided not so much by artistic aspirations as by the possibility of creating a picture of the past, relying on their own real-life experiences.

In the article, the folkloristic narrative research is combined with the concept of trauma theory. On the one hand, life story is seen as a specific text characterised by its relation to a specific cultural background and historical framework. On the other hand, the trauma theory perspective allows to observe the universality of trauma, the interrelation between the events that affect society and the related identity changes. Generally, the narrators do not use the term "trauma". The texts also lack the topics of being a victim and asking for forgiveness, which are typical of trauma theory approaches. These manuscripts may include discussions of cultural trauma-related public life, but in this case the dialogue between the public attitudes and the narrator's own experience can be seen rather as a reflection effect or following an example. This makes the life stories unique carriers of information, because they cannot be treated as miniature forms of the trauma culture that is accepted in society or globally.

The aim of the comparative analysis of the two stories was to outline the specific features of the language of trauma in a life story. The language of trauma in life stories refers on the one hand to the formation of the narrator's life truth, and on the other hand, to the presentation that spares the narrator. Traumatic experiences can be distinguished from the story, for example, based on how the narrator associates one or another aspect with the events of his/her life and the formation of beliefs that stem from the life events. These aspects emerge both through the reasoning and through constant repetitions. The descriptions of particularly hard experiences (e.g. life in Stalinist prison camp, divorce) stand out in the stories for their brevity and laconicism. This results from the emotional state of the narrator, the first-person character in the story, at the time of remembering the events or the situation, but on the other hand also from self-defence - the storyteller is unwilling to relive the situation again while narrating. The story presents traumatic experiences in firm connection with other episodes and deliberations, whereby the traumatic experience is positioned in its place in the narrator's, the first-person character's development story. The stories also imply that there are other traumatic experiences, which the narrator does not reveal. However, the dynamism of the trauma comes significantly to the fore: an individual's each trauma experience absorbs new aspects and associations, thus pointing to stages in the development of the individual, as well as to the changeability of the relationships between the individual and the community. 